\title{
Design, Fabrication, and Initial Operation of HTGR-ORR Capsule OF-2
}

\author{
K. R. Thoms \\ M. J. Kania
}

\section{MASTER}

\section{OAK RIDGE NATIONAL LABORATORY}

OPFRATED BY IINION CARBIDE CORPORATION FOR THE ENERGY RESEARCH AND DEVELOPMENT ADMINISTRATION 


\section{DISCLAIMER}

This report was prepared as an account of work sponsored by an agency of the United States Government. Neither the United States Government nor any agency Thereof, nor any of their employees, makes any warranty, express or implied, or assumes any legal liability or responsibility for the accuracy, completeness, or usefulness of any information, apparatus, product, or process disclosed, or represents that its use would not infringe privately owned rights. Reference herein to any specific commercial product, process, or service by trade name, trademark, manufacturer, or otherwise does not necessarily constitute or imply its endorsement, recommendation, or favoring by the United States Government or any agency thereof. The views and opinions of authors expressed herein do not necessarily state or reflect those of the United States Government or any agency thereof. 


\section{DISCLAIMER}

Portions of this document may be illegible in electronic image products. Images are produced from the best available original document. 
Printed in the United States of America. Available from National Technical Information Service

U.S. Department of Commerce

5285 Port Royal Road, Springfield, Virginia 22161

Price: Printed Copy $\$ 4,50$; Microfiche $\$ 3.00$

This report was prepared as an account of work sponsored by the United States Government. Neither the United States nor the Energy Research and Development Administration/United States Nuclear Regulatory Commission, nor any of their employees, nor any of their contractors, subcontractors, or their employees, makes any warranty, express or implied, or assumes any legal liability or responsibility for the accuracy, completeness or usefulness of any information, apparatus, product or process disclosed, or represents that its use would not infringe privately owned rights. 
ORNL/TM-5459

Dist. Category UC-77

Contract No. w-7405-eng-26

Engineering Technology Division

DESIGN, FABRICATION, AND INITIAL OPERATION OF HTGR-ORR CAPSULE OF-2

K. R. Thoms

M. J. Kania

Manuscript Completed - February 24, 1977

Date Published - March 1977

NOTICE: This document contains information of a preliminary nature. It is subject to revision or correction and therefore does not represent a final report.

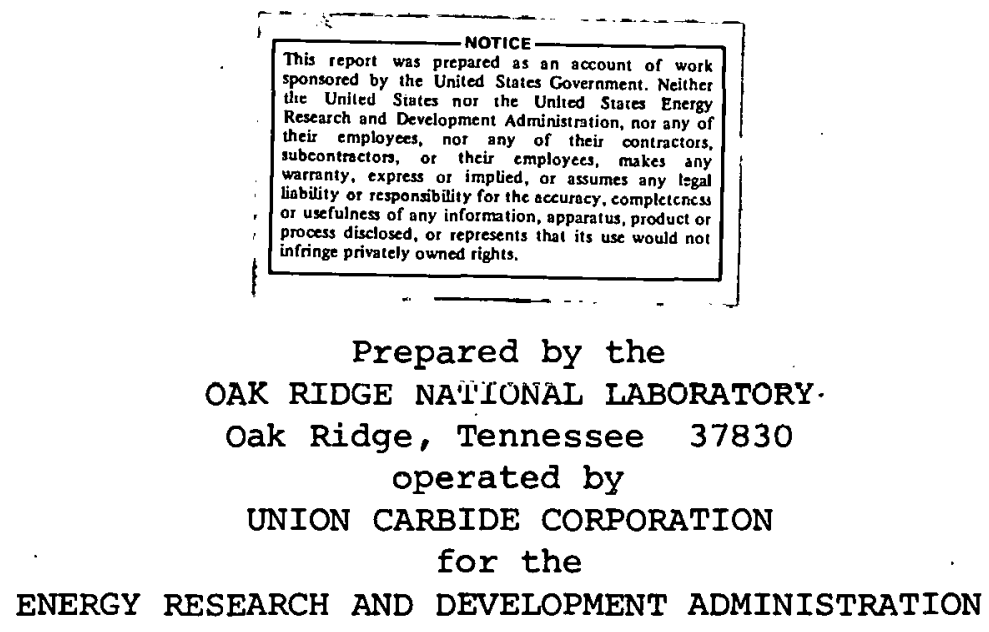




\section{THIS PAGE}

\section{WAS INTENTIONALLY LEFT BLANK}




\title{
DESIGN, FABRICATION, AND INITIAL OPERATION OF HTGR-ORR CAPSULE OF-2
}

\author{
K. R. Thoms \\ M. J. Kania*
}

\section{ABSTRACT}

\begin{abstract}
The OF-2 irradiation experiment was designed and built to test candidate High-Temperature Gas-Cooled Reactor (HTGR) fuel and fuel-rod matrix designs. The capsule was designed with two separate specimen cells, allowing for independent temperature control as well as independent fission gas release measurements. The $\mathrm{OF}-2$ capsule is presently operating at the Oak Ridge Research Reactor (ORR). Initial fuel rod linear heat rates are between 16.4 and $23.0 \mathrm{~kW} / \mathrm{m}$ ( 5 and 7 $\mathrm{kW} / \mathrm{ft}$ ) and fuel centerline temperatures are approximately 1150 and $1350^{\circ} \mathrm{C}$. Plans are to operate the capsule for nine ORR cycles to accumulate a maximum damage fluence of $9 \times 10^{21}$ neutrons $/ \mathrm{cm}^{2}(\mathrm{E}>0.18 \mathrm{MeV})$.
\end{abstract}

\section{INTRODUCTION}

The High-Temperature Gas-Cooled Reactor (HTGR) fuel irradiation experiments conducted at Oak Ridge National Laboratory (ORNL) in support of the Thorium Utilization and Fueled Graphite Development programs have traditionally been accomplished in two phases. The High-Flux Isotope Reactor (HFIR) target series of experiments (HT) are used to screen potential fuel and fuel-rod matrix designs and identify poor performers. Successful degigns are translated into prototype fuels and fuel-rod matrix designs and irradiated in the instrumented facilities in the HFIR removable beryllium (HRB) facilities and the ORR. The OF-2 experiment will supplement information from previously conducted HT and HRB tests. In addition, OF- 2 represents the first test of Triso-coated fissile fuel fabricated in the 13-cm-diam coating furnace at ORNL. The objectives of this experiment are listed below.

*Metals and Ceramics Division. 
1. To test the performance of reference weak-acid resin (WAR), Triso-coated fissile particles and reference Biso-coated fertile particles both coated in the 13-cm-diam coating furnace.

2. To investigate the matrix-particle interaction phenomenon. This portion of the experiment will involve a study of the effects of particle strength, matrix type, and particle surface conditions on irradiation performance.

3. To investigate the behavior under irradiation of various coating microstructures arising from variation of the coating process parameters: gas concentration, deposition rate, deposition temperature, and batch size.

4. To investigate the influence of stoichiometry and kernel density on the irradiation performance of WAR-derived fuels.

5. To verify the adequate performance of fissile and fertile fuels that will be irradiated at a later date in early proof-test elementi in the Fort St. Vrain Reactor.

6. To compare the performance of coatings deposited in the $13-\mathrm{cm}$ coating furnace using a fritted gas distribution system with coatings deposited using a cone gas distributor. The fritted system is the present reference for the HTGR Recycle Demonstration Facility (HRDF).

7. To test our ability to remove fuel rods from the graphite holder after full-life irradiation, particularly as this applics to in-block earbonizatiol'.

This report discusses the design, fabrication, and initial operation of the OF-2 capsule. Another report covering the speration and postirradiation examination will be issued following snmplptinn of those tasks.

\section{IRRADIATION FACILITY}

The OF-2 capsule is being irradiated in the E-7 position of the ORR core. A cross section of the ORR core showing the location of OF-2, as well as other capsules in the HTGR irradiation program, is shown in Fig. 1. Figure 2 shows the installation of the OF-2 capsule in the 
ORNL-DWG 75-15687

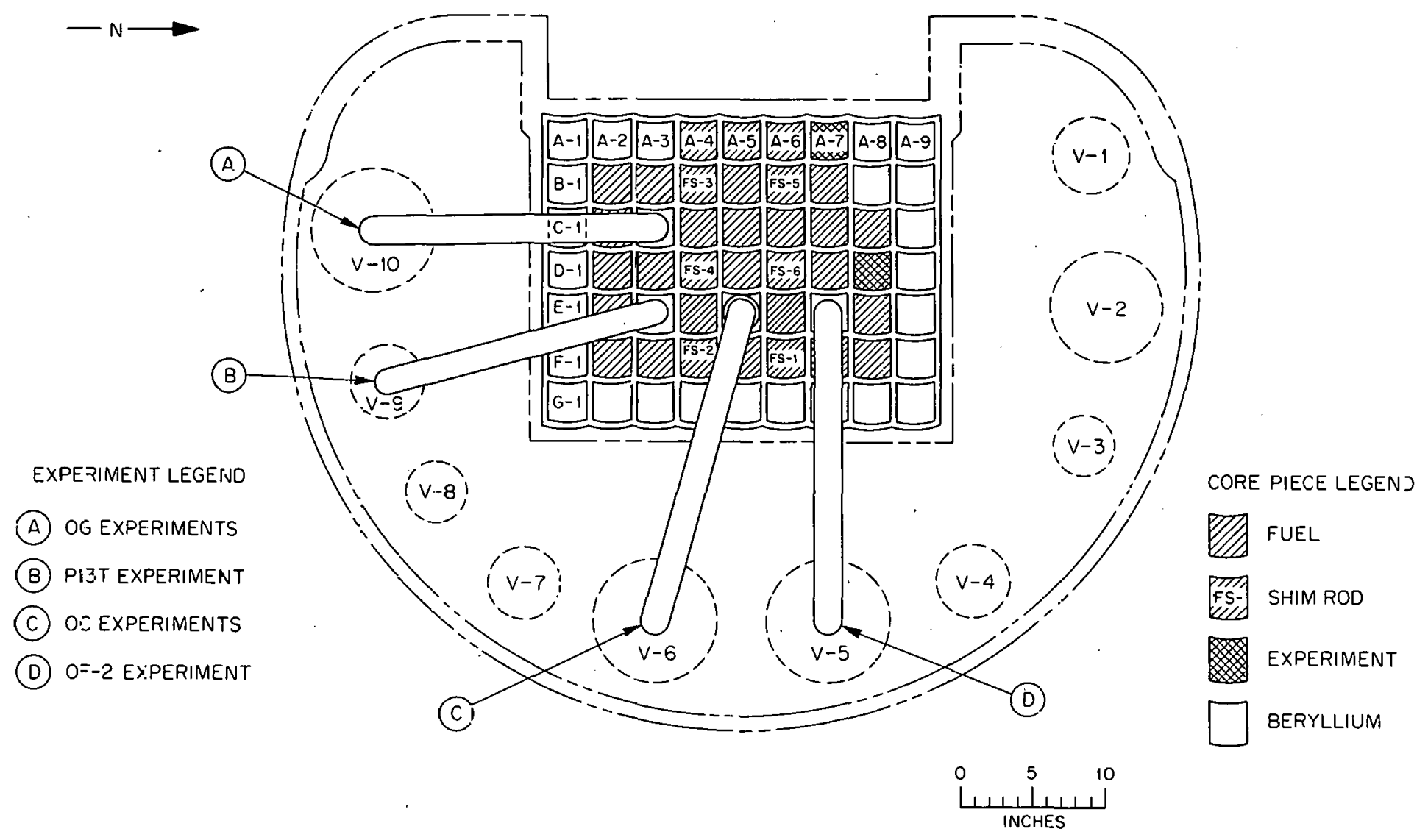

Fig. 1. HTGR irradiation experiment locations in the ORR. 


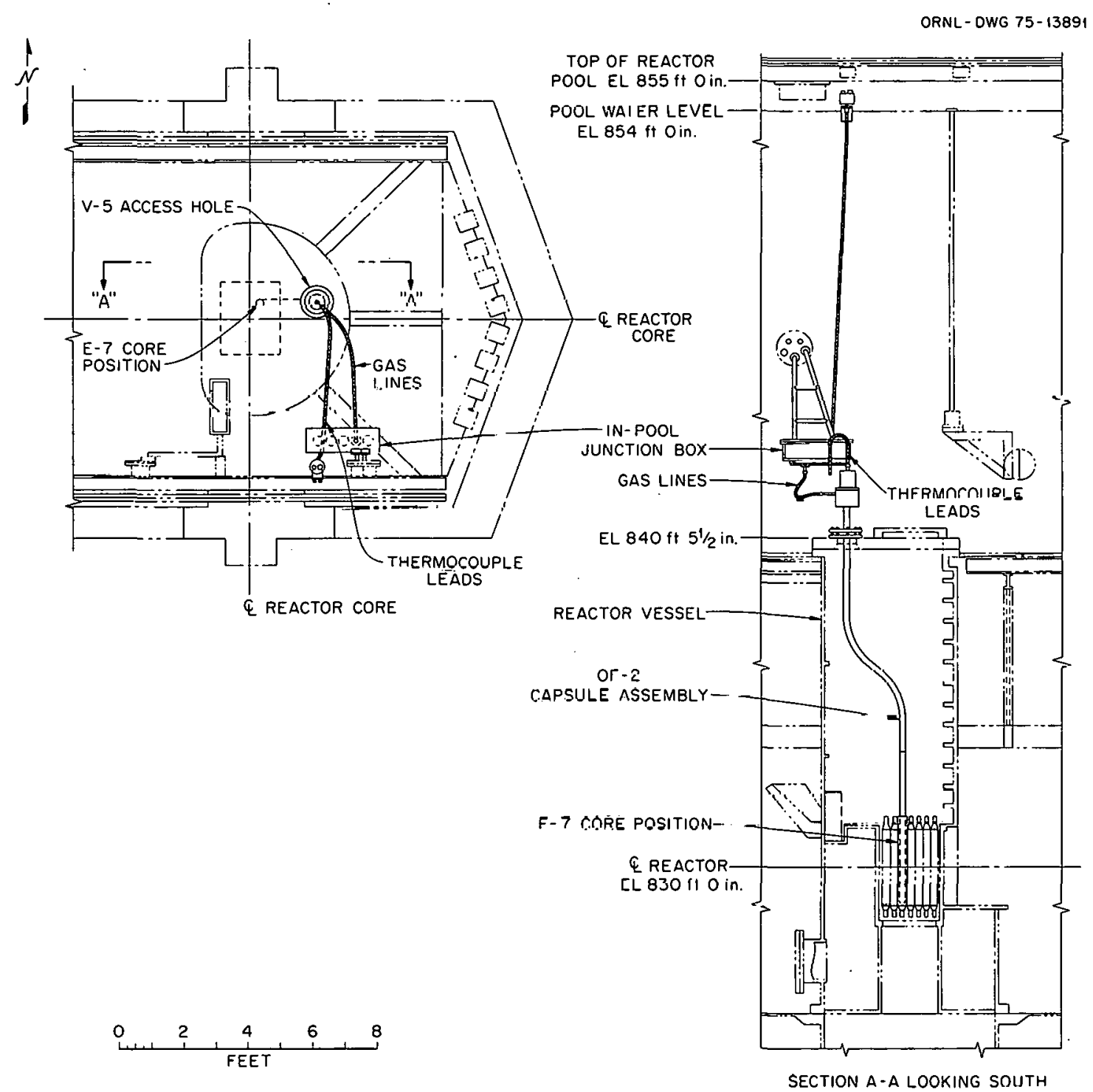

Fig. 2. Installation of $\mathrm{OF}-2$ capsule in $\mathrm{ORR}$ ( $1 \mathrm{ft}=0.3048 \mathrm{~m}$ ). 
ORR pool. The thermocouple leads that run to the top of the pool are connected to the lead wires that feed into recorders and a data-acquisition system. Gas lines coming from the capsule are fed into the in-pool junction box, where they are connected to existing gas supply and vent systems. A schematic flow diagram of the OF-2 capsule is presented in Fig. 3.

\section{EXPERIMENTAL ASSEMBIY}

The description of the experimental assembly is divided into four parts: the capsule design, the instrumentation used to monitor operation, the dosimetry incorporated to determine neutron fluxes, and the fuel specimens.

\subsection{Capsule Design}

The general configuration of capsule $\mathrm{OF}-2$ is shown in Fig. 4. The three fuel specimen holders are doubly contained in two type 304 stainless steel containment vessels. The inner or primary containment vessel is $63.19 \mathrm{~cm}(24.88 \mathrm{in.})$ long and has a $6.195-\mathrm{cm}(2.439-\mathrm{in.})$ ID and a 6.447-cm (2.539-in.) OD. The outer or secondary containment vessel is $81.92 \mathrm{~cm}$ (32.25 in.) long with a $6.464-\mathrm{cm}(2.545-\mathrm{in.})$ ID and a $6.668-$ $\mathrm{cm}$ (2.625-in.) OD. The total active test space is a cylinder $63.50 \mathrm{~cm}$ (25.0 in.) long and $6.05 \mathrm{~cm}(2.38 \mathrm{in.})$ in diameter. The capsule is divided into two cells by a copper bulkhead brazed into the primary containment vessel at a point $8.573 \mathrm{~cm}$ (3.375 in.) below the reactor midplane and approximately $36.8 \mathrm{~cm}$ (14.5 in.) below the upper end of the capsule.

The bottom cell (cell 1) contains one H-45l graphite specimen holder (designated specimen holder $\mathrm{C}$ ), which is $22.23 \mathrm{~cm}$ ( $8.750 \mathrm{in.}$ ) long and $6.1054 \mathrm{~cm}$ (2.4037 in.) in diameter. The specimen holder has a 0.953-cmdiam (0.375-in.) central spline hole and four 1.595-cm-diam (0.628-in.) peripheral fuel holes. Each fuel hole contains four 5.08-cm-long (2.00in.) by $1.575-\mathrm{cm}$-diam (0.620-in.) fuel rods. Nine Chromel-P/Alumel (C/A) thermocouples are incorporated to monitor peripheral graphite temperature 


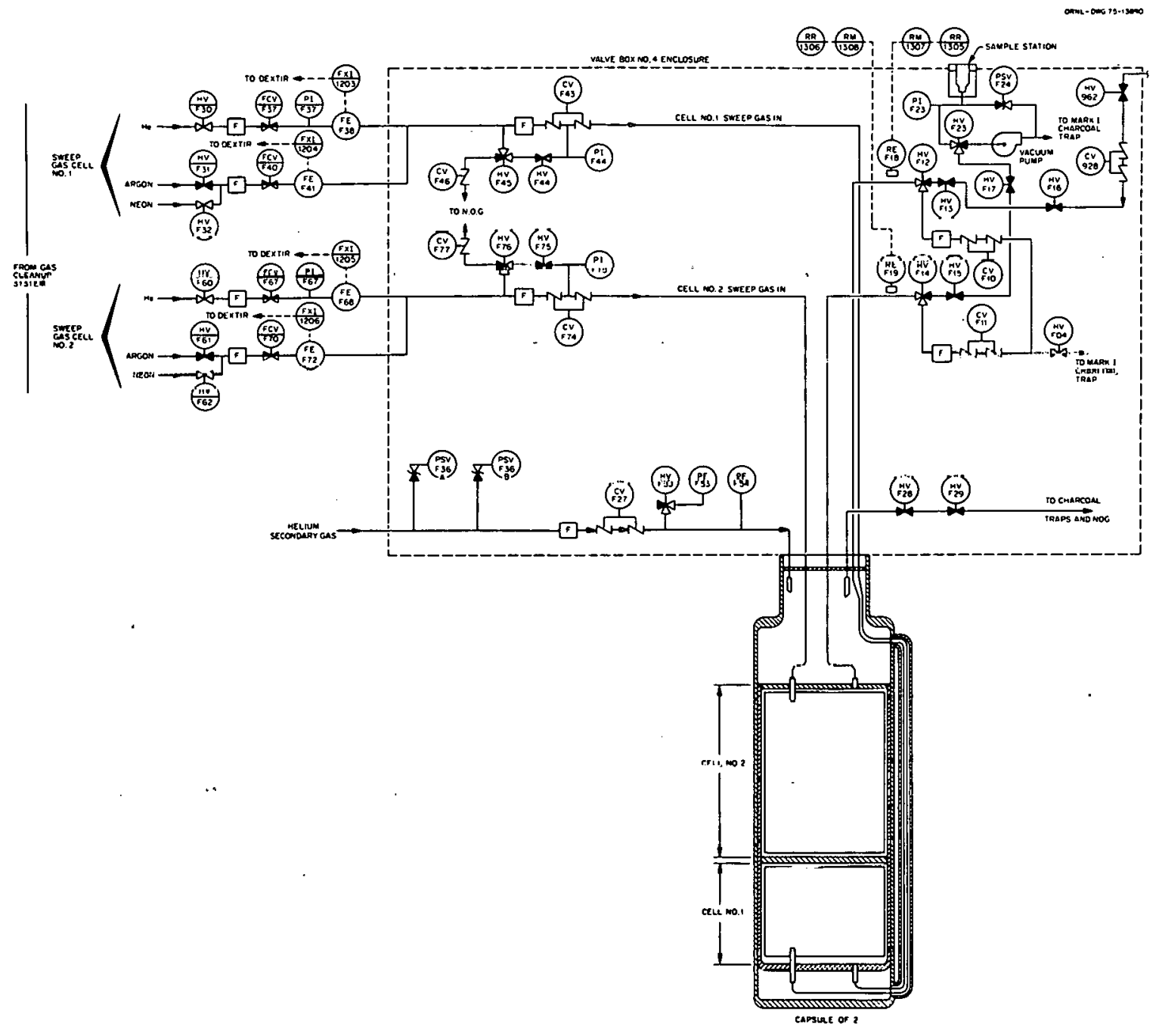

Fig. 3. Schematic flow diagram for capsule oF-2. 


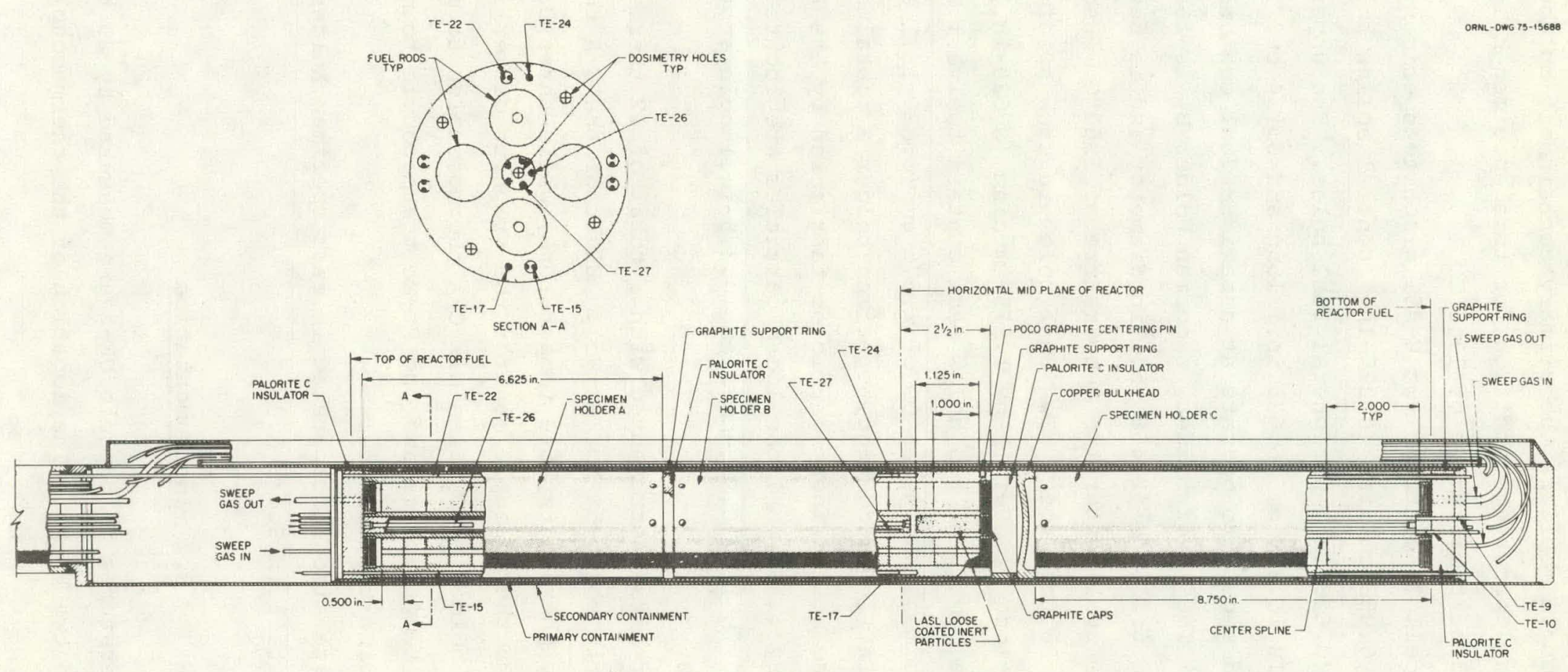

Fig. 4. General configuration of capsule $\mathrm{OF}-2$ ( 1 in. $=2.54 \mathrm{~cm}$ ). 
and one $C / A$ thermocouple monitors the primary containment bulkhead temperature. The design operating condition for this specimen holder is a maximum fuel centerline temperature of $1350^{\circ} \mathrm{C}$.

The top cell (cell 2) contains two H-451 graphite specimen holders, each of which has a $0.953-\mathrm{cm}$-diam (0.375-in.) central spline hole and four 1.595-cm-diam (0.628-in.) peripheral fuel holes. The upper holder, specimen holder $A$, is $16.828 \mathrm{~cm}$ (6.625 in.) long and $6.134 \mathrm{~cm}$ (2.415 in.) in diameter and is designed to operate at a maximum fuel centerline temperature of $1150^{\circ} \mathrm{C}$. The lower holder, specimen holder $\mathrm{B}$, is $16.828 \mathrm{~cm}$ (6.625 in.) long and $6.116 \mathrm{~cm}(2.408 \mathrm{in.)}$ in diameter and is desiyned to operate at a maximum fupl centerlino tempcrature of $1350^{\circ} \mathrm{C}$. Each spec1men holder contains 36 fuel rods. Two fuel holes in each specimen holder contain six $2.54-\mathrm{cm}$-long $(1.00-\mathrm{in.})$ by $1.575-\mathrm{cm}$-diam $(0.620-$ in.) fuel specimens, while the remaining two holes each contain twelve 1.27-cm-long $(0.50-i n$.$) fuel specimens having an OD of 1.575 \mathrm{~cm}(0.620 \mathrm{in.})$ and an ID of $0.340 \mathrm{~cm}$ ( $0.134 \mathrm{in.)}$. In addition, specimen holder B contains approximately $2 \mathrm{~cm}^{3}$ of loose coated inert particles fabricated by Los Alamos Scientific Laboratory (LASL). These loose particles are located in a 3.175-cm-long (1.250-in.) by $0.953-\mathrm{cm}$-diam $(0.375-\mathrm{in}$.$) hole at the bottom$ of specimen holder $B$.

Specimen holder $A$ is instrumented with a total of 12 thermocouples $11 \mathrm{C} / \mathrm{A}$ and one Pt-0.18 Mo/Pt-5\% Mn (Pt-Mo). Eight of the C/A thesmucuuples monitor the peripheral graphite temperature, while three C/A Lliermucouples and the Pt-Mo thermocouple monitor the graphite centerline temperature. Specimen holder B contains six C/A thermocouples to monitor graphite peripheral temperatures and one Pt-Mo thermocouple to monitor the graphite centerline temperature.

Flux monitors are also incorporated in each specimen holder and are described in more detail in sect. 3.3.

\subsection{Instrumentation}

Operating temperatures in capsule OF-2 are measured by 29 thermocouples $-27 \mathrm{C} / \mathrm{A}$ and two Pt-Mo. The location of the thermocouples is shown in Fig. 5 . 


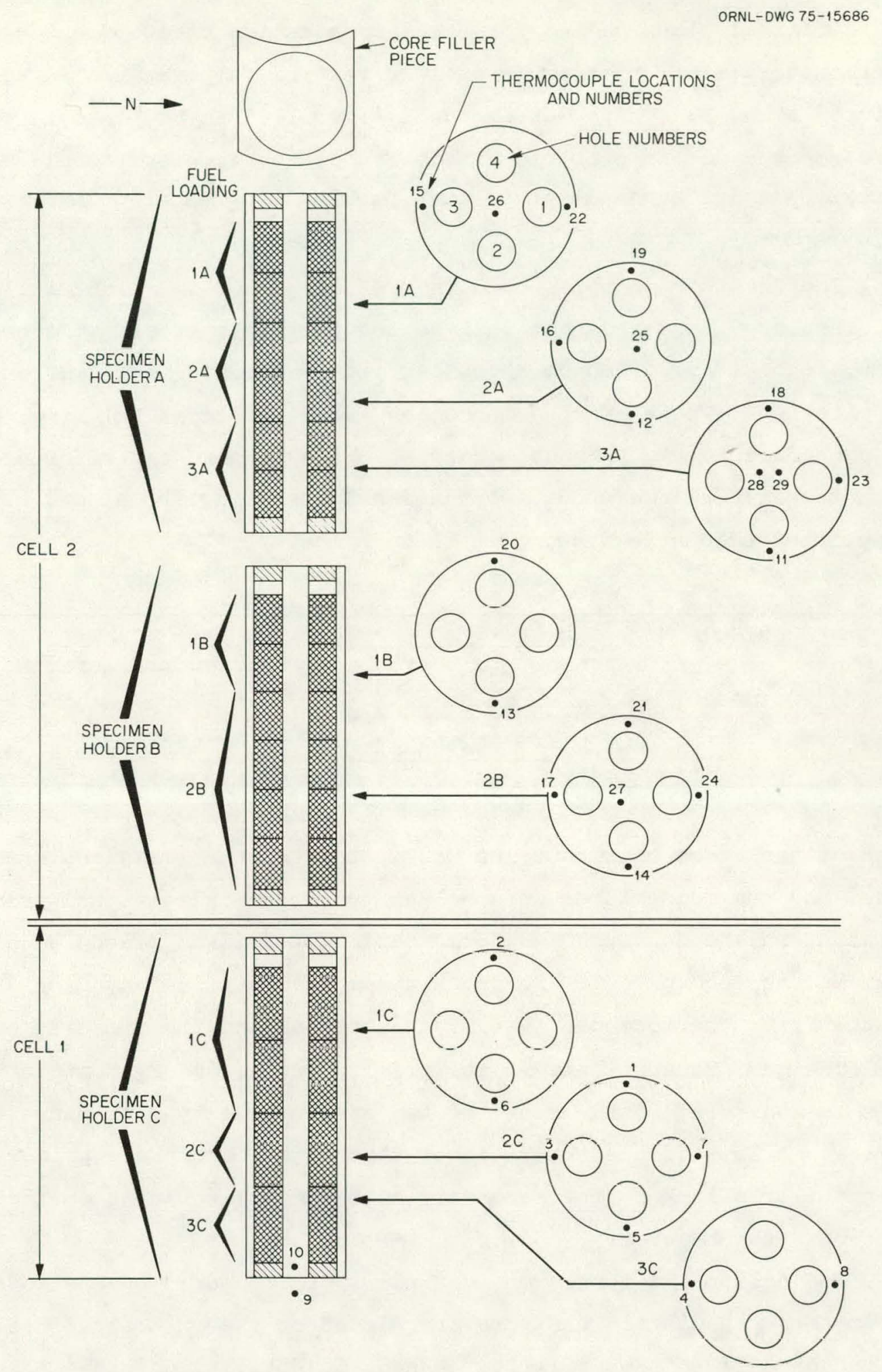

Fig. 5. General layout of specimen holders, fuel loadings, and thermocouples in capsule $\mathrm{OF}-2$. 
Original plans called for the incorporation of two Johnson noise thermometers (JNT) to measure fuel centerline temperatures in specimen holders $A$ and $B$. These were actually installed in the capsule, but they were removed due to problems discovered at the time of capsule assembly. A more detailed explanation of this problem is presented in Chap. 5 of this report.

The C/A thermocouples used in $\mathrm{OF}-2$ are $0.160 \mathrm{~cm}$ (0.063 in.) OD, Mgo insulated, and sheathed in type 304 stainless steel. The two Pt-Mo thermocouples are $0.160 \mathrm{~cm}$ (0.063 in.) OD, alumina insulated, and sheathed in platinum. The Pt-Mo thermocouples are $91.44 \mathrm{~cm}$ (3 ft) long, and each is connected to two $\mathrm{C} / \mathrm{A}$ thermocouples which measure the reference junction temperature and provide extension leads using the Alumel wires. A simplified schematic drawing is shown below.

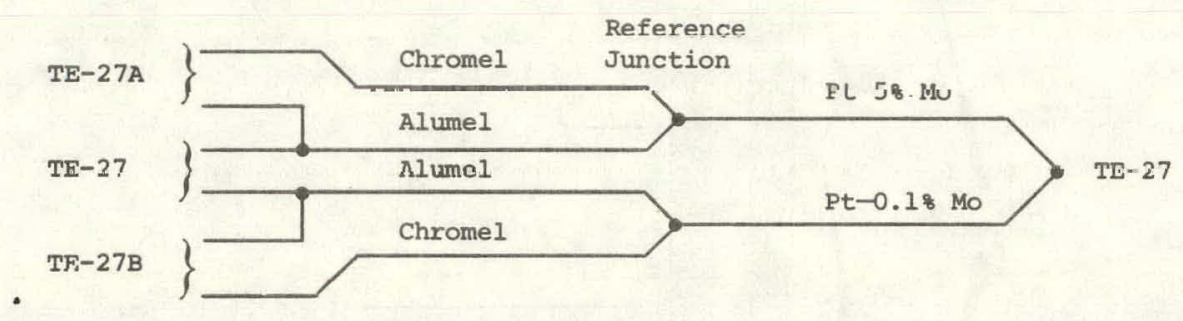

Each of the Pt-Mo thermocouples was installed in a stainless steel guide tube, and the guide tubes were welded to the stainless steel primary containment bulkhead. One C/A thermocouple (TE-29) was placed adjacent to a Pt-Mo thermocouple $(\mathrm{TE}-28)$ in an attempt to measure any decalibration in the Pt-Mo thermocouple that might occur during the irradiation period.

The gas pressure between the primary and secondary containment vessels is monitored continuously by two strain-gage-type pressure transducers. A loss of pressure, either through a leak in the primary containment or a leak in the secondary containment, would automatically shut down the reactcr.

The helium and neon sweep gas flows are measured by Hastings mass flowmeters. Radiation monitors are placed on the exit sweep gas lines from each cell to show relative changes in activity of gases leaving each cell.

The thermocouple outputs, secondary gas pressure, and activity of sweep gas lines are continuously recorded on millivolt strip-chart 
recorders. In addition to these recorded data, all thermocouple outputs and sweep gas flows are recorded four times per day on a Dextir dataacquisition system. These data are reduced weekly and stored on disks at the computer center. At the end of each reactor cycle, plots are generated to present a cycle history of each thermocouple as well as the sweep gas flow rates and reactor power.

\subsection{Dosimetry}

Flux monitor packages were loaded into specimen holders $A$ and $B$ and the center splines of both cells 1 and 2. The positions of the packages are shown in Fig. 6 along with the arrangement of the monitor wires in each package. The weights of the flux monitor wires in each package are given in Appendix A.

A flux monitor package consists of a Beo tube containing three flux monitor wires - two iron wires $(100 \% \mathrm{Fe})$ and one vanadium-cobalt wire $(\mathrm{V}-0.216 \% \mathrm{CO})$. The wire materials were selected on the basis of their neutronic properties, high melting points, and chemical compatibility with Beo. The Beo tubes prevent interaction of the wires with the graphite.

Neutron fluences in $\mathrm{OF}-2$ will be determined by measuring the induced activities in these wires through the following reactions:

$$
\begin{aligned}
& { }^{59} \mathrm{Co}(n, \gamma){ }^{60} \mathrm{Co} \\
& { }^{54} \mathrm{Fe}(n, p){ }^{54} \mathrm{Mn} \\
& { }^{58} \mathrm{Fe}(n, \gamma){ }^{59} \mathrm{Fe}
\end{aligned}
$$

\subsection{Fuel Specimens}

\subsubsection{Coated particles}

Eighty-eight specimens were required for OF-2. Eighty-six of these were fabricated at $\mathrm{ORNL}$ and the remaining two were fabricated at LASL. The Triso-coated fissle particle test set consisted of twelve batches of WAR-derived particles of a wide range of stoichiometries, from uranium oxide to uranium carbide; one batch of WAR-derived U(C,N) particles; one 


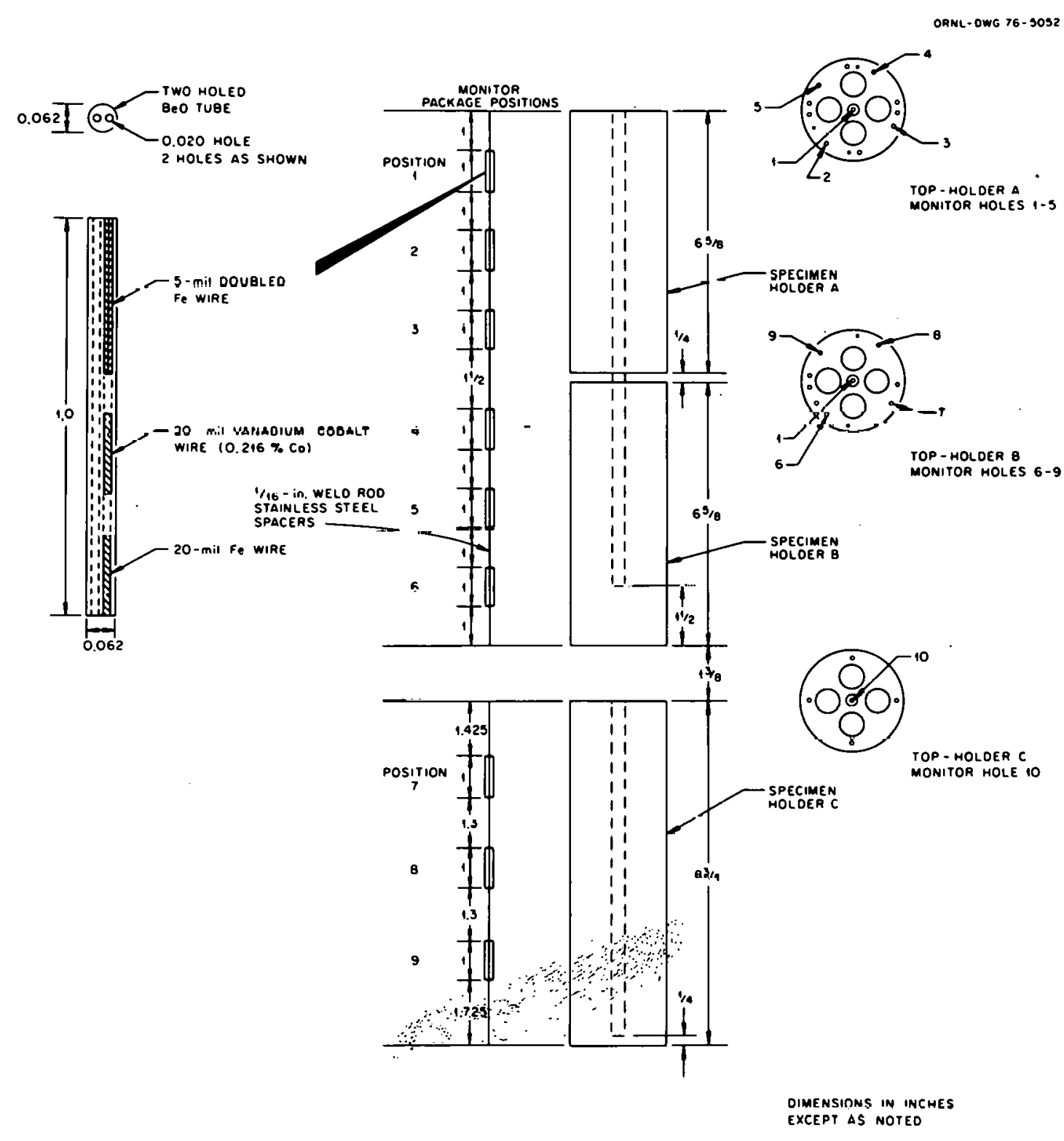

Fif. 6. Arrangement of flux monitors in capsule of-2 (1 in. = $2.54 \mathrm{~cm}$ ). 
batch of sol-gel $(4 \mathrm{Th}, \mathrm{U}) \mathrm{O}_{2}$ particles; and one batch of General Atomic Company's (GAC) VSM UC 2 particles. A complete description of each fissile particle batch is presented in Table 1. All the particle batch types, with the exception of type 15, were included in the fuel specimens in the upper cell, cell 2. Particle types 13, 14, and 15 were fabricated for the lower experimental compartment, cell 1 , using the large diameter coating furnace. Types 13 and 14 were coated using the reference fritted gas distribution system, and type 15 was coated using the cone distribution system. Particle types 1 through 11 were annealed at $1800^{\circ} \mathrm{C}$ for $10 \mathrm{~min}$ in a fluidized bed after the outer low-temperature isotropic (OLTI) coating was deposited. Particle types 13 through 15 were similarly annealed after the inner low-temperature isotropic (ILTI) coating was deposited.

Sixteen batches of Biso-coated fertile particles were selected for OF-2. Nine of the fertile batch types were coated in the large-diameter coating furnace, with batch types $G$ through $J$ and $M$ through $P$ using $a$ fritted gas distributor and batch type $\mathrm{K}$ using the cone distribution system. Specific reference to coating parameters, deposition rates, geometries, and densities are described in Table 2. Fertile particle types A through $\mathrm{L}$ were annealed at $1800^{\circ} \mathrm{C}$ for $10 \mathrm{~min}$ in a fluidized bed, and the remaining types were unannealed.

\subsubsection{Fuel rods}

One batch each of fissile and fertile particles was selected from its respective test set and combined with a particular matrix type for each fuel rod specimen fabricated. The matrix test set for OF-2 is described in Table 3.

Sixteen fuel rod specimens were fabricated for cell 1. Each specimen contained a mixture of Triso-coated fissile particles, Biso-coated fertile particles, Triso- and Biso-coated carbon particles, and $\dot{H}-451$ shim particles. In order to keep fuel rod dimensional changes uniform in this compartment, the ratio of Biso- to Triso-coated particles was kept constant for each loading. Each specimen contained $20 \%$ by volume shim par-

ticles. Specimens were fabricated to nominal dimensions of $1.575 \mathrm{~cm}$ diam $(0.620 \mathrm{in.})$ by $5.08 \mathrm{~cm}$ long (2.00 in.) using the slug-injection technique 
Table 1. Fissile particle test set for GF-?

\begin{tabular}{|c|c|c|c|c|c|c|c|c|c|c|c|c|}
\hline \multirow[b]{2}{*}{ Type } & \multirow[b]{2}{*}{ Batci } & \multirow{2}{*}{$\begin{array}{c}\text { Kernel } \\
\text { composjtion }\end{array}$} & \multirow{2}{*}{$\begin{array}{l}\text { Nominal } \\
\text { reduction } \\
(\%)\end{array}$} & \multirow{2}{*}{$\begin{array}{c}\text { Carboni- } \\
\text { zation } \\
\text { rate } \\
\left({ }^{\circ} \mathrm{Cimin}\right)\end{array}$} & \multirow{2}{*}{$\begin{array}{l}\text { Kernel } \\
\text { density } \\
\left(\mathrm{g} / \mathrm{cm}^{3}\right)\end{array}$} & \multirow{2}{*}{$\begin{array}{c}\text { Coater } \\
\text { type }\end{array}$} & \multirow[b]{2}{*}{ Anneal } & \multicolumn{5}{|c|}{ Geometry $^{b}(\mu \mathrm{m})$} \\
\hline & & & & & & & & Kerrel & Buffer & ILTI & Sic & OLTI \\
\hline 1 & $\mathrm{OR}-2332 \mathrm{H}^{\circ}$ & WAR UC $5.43^{0_{1.95}}$ & 0 & 2 & 3.23 & Cone $^{e}$ & Yes & 373.1 & 39.2 & 32.3 & 32.9 & 32.2 \\
\hline 2 & $O R-2329 \mathrm{H}^{\mathrm{a}}$ & WAR UC $5.53^{0} 1.97$ & 0 & 2 & 3.22 & Cone $^{c}$ & Yes & 371.9 & 23.0 & 40.6 & 31.8 & 30.8 \\
\hline 3 & OR-2218 $\mathrm{H}^{\mathrm{e}}$ & WAR $\mathrm{UC}_{4} .58^{\circ} \mathrm{O}_{\bar{z} .04}$ & 0 & 40 & 3.66 & Cone & Yes & 371.3 & 69.3 & 42.0 & 30.7 & 44.6 \\
\hline 4 & $\mathrm{OR}-2322 \mathrm{H}^{\circ}$ & WAR UC $5.540_{1.69}$ & 15 & 2 & 3.12 & Cone $^{c}$ & Yes & 379.7 & 49.8 & 35.7 & 32.3 & 39.4 \\
\hline 5 & $\mathrm{OR}-2320 \mathrm{H}$ & WAR UC $5.12 \mathrm{O}_{1.54}$ & 25 & 2 & 3.17 & Cone $e^{e}$ & Yess & 374.0 & 43.8 & 36.8 & 34.3 & 38.6 \\
\hline 6 & $\mathrm{OR}-2211 \mathrm{H}^{e}$ & WAR UC $4.63^{0} 0.97$ & 50 & 2 & 3.11 & Cone & Yes & 363.0 & 59.3 & 37.5 & 30.2 & 42.0 \\
\hline 7 & $\mathrm{OR}-2207 \mathrm{H}^{\epsilon, g}$ & WAR UC ${ }_{4} .140_{0.53}$ & 75 & 2 & 3.03 & Cone $e^{c}$ & Yes & 366.4 & 62.7 & 38.9 & 31.1 & 42.7 \\
\hline 8 & $\mathrm{OR}-2208 \mathrm{H}^{e}$ & WAR $\mathrm{UC}_{3.68} 0_{0.01}$ & 100 & 2 & 3.01 & Cone $e^{c}$ & Yes & 366.5 & 59.2 & 38.4 & 27.9 & 40.0 \\
\hline 9 & $\mathrm{OR}-2121 \mathrm{H}^{\bar{R},}, e, \subseteq$ & WAR $\mathrm{UC}_{2.6100 .16}$ & $\Xi 00$ & 6 & 5.28 & Cone $e^{c}$ & Yes & 315.3 & 74.6 & 36.1 & 28.4 & 49.2 \\
\hline 10 & OR-2219H & WAR UC $3.68^{\mathrm{N}_{0}} 0.53$ & & 2 & 3.02 & & Yes & 365.3 & 66.3 & 44.0 & 31.9 & 43.5 \\
\hline 11 & $O R-2321 H^{-3}$ & Sol-gel $\left(\mathrm{Th}_{0.8} \mathrm{U}_{0.2}\right) \mathrm{O}_{2}$ & & & 9.9 & & Yes & 361.1 & 83.3 & 37.2 & 34.4 & 41.1 \\
\hline 12 & 6151-00-035 & VSH $\mathrm{UC}_{2}$ & & & 10.99 & & & 196.0 & 99 & 33 & 32 & 38 \\
\hline 13 & $A-601$ & WAR & 75 & 2 & 3.03 & Frit & No & 354.2 & 58.8 & $35.4^{j}$ & 30.0 & 35.8 \\
\hline 14 & $A-611$ & WAR & 15 & 2 & 3.10 & Frit $\dot{\bar{z}}$ & No & 366.4 & 47.6 & 36.8 & 30.5 & 35.5 \\
\hline 15 & $A-615$ & WAR & 75 & 2 & 3.08 & Cone $e^{k}$ & No & 354.1 & 51.0 & $30.7^{j}$ & 29.5 & 32.4 \\
\hline
\end{tabular}

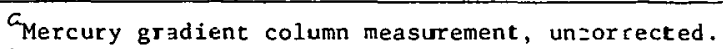

Mean dimension: for kernel diameter, bufier, ILTI, SiC, and OLTI thickness.

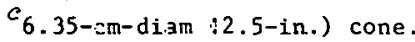

$\mathcal{Z}_{\text {Thin juffe: }}$

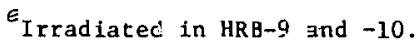

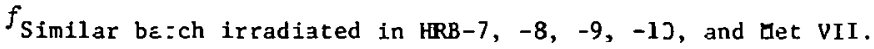

${ }^{9}$ Irradiated in Dragon. Met VII.

$h$ Irradiatec in $\mathrm{HR}^{-}-7$ and -8 .

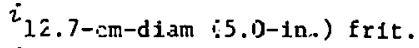

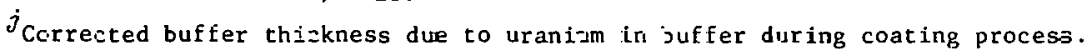

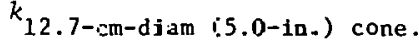


Table 2. Fert1le particle test for OF-2

\begin{tabular}{|c|c|c|c|c|c|c|c|c|c|c|c|c|c|c|}
\hline \multirow[b]{2}{*}{ Type } & \multirow[b]{2}{*}{ 3atch. } & \multirow[b]{2}{*}{$\begin{array}{l}\text { Coater } \\
\text { type }\end{array}$} & \multicolumn{4}{|c|}{ Coating parameters } & \multicolumn{2}{|c|}{ LTI deposition } & \multicolumn{3}{|c|}{ Geometry ${ }^{b}(\mu \mathrm{m})$} & \multicolumn{2}{|c|}{ Density ${ }^{c}\left(\mathrm{~g} / \mathrm{cm}^{3}\right)$} & \multirow[b]{2}{*}{ Anneal } \\
\hline & & & $\operatorname{Gas}^{\alpha}$ & $\begin{array}{l}\text { Concen- } \\
\text { trat fon } \\
(\%)\end{array}$ & Diluent & $\begin{array}{l}\text { Concen- } \\
\text { tration } \\
(\%)\end{array}$ & $\begin{array}{l}\text { Temper- } \\
\text { ature } \\
\left({ }^{\circ} \mathrm{C}\right)\end{array}$ & $\begin{array}{c}\text { Rate } \\
(\mu \mathrm{m} / \mathrm{min})\end{array}$ & Kernel & Buffer & LTI I & Uncorrected & Corrected & \\
\hline A & $\mathrm{OR}-2 \approx 66 \mathrm{HT}^{d}$ & Cone $e^{e}$ & MAPP & 100 & & & 1275 & 14.1 & 506 & 94.8 & 91.3 & 2.02 & & Yes \\
\hline B & $\mathrm{OR}-2 \varepsilon 65 \mathrm{HT}^{d}$ & Cone $e^{e}$ & MAPP & 100 & & & 1325 & 15.7 & 508 & 96.1 & 94.2 & 1.95 & & Yes \\
\hline$c$ & $\mathrm{OR}-2 \tilde{\varepsilon} .62 \mathrm{HT}{ }^{d}$ & Cone $e^{e}$ & MAPP & 50 & Ar & so & 1275 & 6.5 & 507 & $98.0^{\circ}$ & 85.1 & 2.01 & & Yes \\
\hline D & $\mathrm{OR}-2 \ddot{i} 61 \mathrm{HT}^{d}$ & Cone $e^{e}$ & MAP? & 50 & Ar & 50 & 1325 & 7.4 & 506 & 95.8 & 88.9 & 1.89 & & Yes \\
\hline E & $\mathrm{OR}-2264 \mathrm{HT}^{d}$ & Cone $^{e}$ & MAFP & 25 & Ar & 75 & 1275 & 3.2 & 507 & 96.5 & 91.6 & 1.99 & & Yes \\
\hline $\mathbf{F}$ & $\mathrm{OR}-2263 \mathrm{HT}$ & Cone $e^{e}$ & MAPP & 25 & Ar & 75 & 1325 & 3.6 & 506 & 92.8 & 90.5 & 1.84 & & Yes \\
\hline G & $\mathrm{J}-488^{d, f}$ & Frit $^{g}$ & $\mathrm{C}_{3} \mathrm{H}_{6}$ & 50 & $\mathrm{He}$ & 50 & 1375 & 7.4 & 497.9 & 82.7 & 30.7 & 1.98 & 1.87 & Yes ' \\
\hline H & $\mathrm{J}-489^{d}$ & $\operatorname{Fr} 1 t^{g}$ & $\mathrm{C}_{3} \mathrm{H}_{6}$ & 50 & He & 50 & 1375 & 5.8 & $\angle 99.0$ & 81.4 & 77.7 & 1.90 & 1.79 & Yes \\
\hline I & $\mathrm{J}-490^{d}$ & Frit $^{g}$ & $\mathrm{C}_{3} \mathrm{H}_{6}$ & 100 & & & 1375 & 6.2 & 495.9 & 80.2 & 74.7 & 1.99 & 1.86 & Yes \\
\hline $\mathrm{J}$ & $\mathrm{J}-491^{d}$ & Frit $^{g}$ & $\mathrm{C}_{3} \mathrm{H}_{6}$ & 100 & . & & 1375 & 9.3 & 497.1 & 79.5 & 77.5 & 2.00 & 1.86 & Yes \\
\hline $\mathrm{K}$ & $\mathrm{J}-262^{h}$ & Cone $^{i}$ & $\mathrm{C}_{3} \mathrm{H}_{6}$ & 100 & & & 1350 & 8.4 & 497 & 84.0 & 86.1 & 2.01 & & Yes \\
\hline L & $\mathrm{OR}-1349 \mathrm{HT}$ & Cone $e^{j}$ & $\mathrm{C}_{3} \mathrm{H}_{6}$ & 75 & He & 25 & $1400^{k}$ & 21.5 & 508 & 79.4 & 74.7 & 1.94 & & Yes \\
\hline M & $J-48 t^{7}$ & Frit $^{g}$ & $\mathrm{C}_{3} \mathrm{H}_{6}$ & 50 & Ke & 50 & 1375 & 7.4 & 497.9 & 82.7 & 80.7 & 1.94 & 1.84 & No \\
\hline $\mathbf{N}$ & $J-483$ & Frit $^{g}$ & $\mathrm{C}_{3} \mathrm{H}_{6}$ & 100 & & & 1375 & 6.2 & 495.9 & 80.2 & 74.7 & 1.96 & 1.83 & No \\
\hline 0 & $\mathrm{~J}-482$ & Frit $^{g}$ & $\mathrm{C}_{3} \mathrm{H}_{6}$ & 50 & $\mathrm{He}$ & 50 & 1375 & 5.8 & 499.0 & 81.4 & 77.7 & 1.88 & 1.78 & No \\
\hline $\mathbf{p}$ & $J-487$ & Frit $^{g}$ & $\mathrm{C}_{3} \mathrm{H}_{6}$ & 100 & & & 1375 & 9.3 & 497.1 & 79.5 & 77.5 & 1.95 & 1.81 & No \\
\hline
\end{tabular}

a MAPP gas is marketed by AIRCO, Inc., and consists primarily of methylacetylene and propadiene, with alkanes and stabilizers.

$b$ Mean dimensions for kernel diameter, buffer, and LTI thicknesses,

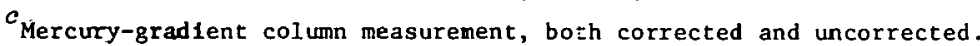

$d_{\text {Iriadiated in HT- } 30 .}$.

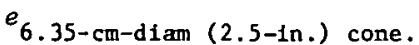

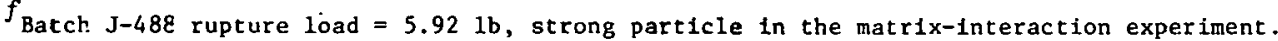

g12.7-cm-diam (5.0-in.) frit.

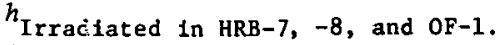

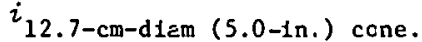

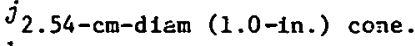

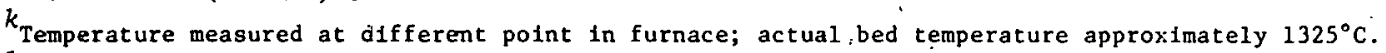

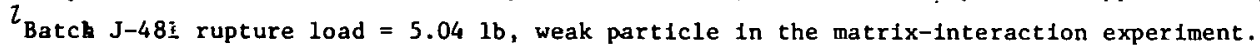


Table 3. Matrix test set for OF-2.

\begin{tabular}{llllll}
\hline Type & Pitch & Additive & Filler & $\begin{array}{c}\text { Expected } \\
\text { coke } \\
\text { yield } \\
(\%)\end{array}$ & $\begin{array}{c}\text { Carbonization } \\
\text { technique }\end{array}$ \\
\hline a & A-240 & None & Asbury 6353 & $20-25$ & $\mathrm{Al}_{2} \mathrm{O}_{3}$ \\
b & A-240 & None & Asbury 6353 & $35-40$ & $\begin{array}{l}\text { In tube } \\
\text { In block } \\
\text { C }\end{array}$ \\
GAC & Proprietary & Asbury 6353 & $20-25$ & $15-20$ & Graphite flour \\
\hline
\end{tabular}

and matrix type c. Specimens were injected at $180^{\circ} \mathrm{C}$ and $5.54 \mathrm{MPa}(800$ psi) except for rods containing fertile particle types $M$ and $N$, which were injected at $4.16 \mathrm{MPa}$ (600 psi). Placement of fuel rod specimens in cell 1 was based upon a statistical experimental design in order to minimize interaction effects. Carhnnization was dono ucing the referelice inblock technique with a heating rate of $11.5^{\circ} \mathrm{C} / \mathrm{min}$, producing a coke yield of 25.7\%. All fuel rods were subjected to a final heat treatment at $1800^{\circ} \mathrm{C}$ in argon for $30 \mathrm{~min}$. The fissile and fertile particle types and matrix type, along with the total weights of ${ }^{235} \mathrm{U}$ and ${ }^{232} \mathrm{Th}$ used in each fuel rod of specimen holder $C$, are presented in Appendix $B$.

A total of 72 fuel rod specimens were fabricated for cell 2. Two of these specimens were fabricated by LASI, and 70 were fabricated by ORNL. The two LASL-fabricated fuel rods consisted of GAC Triso-coated fissile particles, LASL-graded ZrC-coated fissile particles, GAC Biso-coated fertile particles, M-3 graphite flour, and Varcum binder. These two specimens were fabricated to nominal dimensinns of $1.575 \mathrm{om}$ diam $(0.620$ in.) by $1.27 \mathrm{~cm}$ long $(0.500 \mathrm{in}$.).

The 70 ORNL-fabricated specimens contained a mixture of Triso-coated fissile particles, Biso-coated fertile particles and Biso-cnater rarbon particles. All 70 specimens were fabricated using the slug-injection technique. Forty-six of the specimens were fabricated to nominal dimensions of $1.575 \mathrm{~cm}$ OD $(0.620 \mathrm{in.})$ by $0.330 \mathrm{~cm}$ ID $(0.130 \mathrm{in.})$ by $1.27 \mathrm{~cm}$ long ( 0.500 in.) using matrix type $d$ with 28.5 wt \& Asbury 6353 graphite in Ashland Oil Company A-240 petroleum pitch. They were injected at $180^{\circ} \mathrm{C}$ and $4.16 \mathrm{MPa}(600 \mathrm{psi})$ and carbonized in a bed of high-fired $\left(3000^{\circ} \mathrm{C}\right)$ 
graphite flour, using a heating rate of $1^{\circ} \mathrm{C} / \mathrm{min}$. Twenty-four fuel specimens were fabricated to nominal dimensions of $1.575 \mathrm{~cm}$ diam (0.620 in.) by $2.54 \mathrm{~cm}$ long ( $1.00 \mathrm{in.)}$ using matrix types $\mathrm{a}, \mathrm{b}$, and $\mathrm{c}$. Matrix types $a$ and $b$ are the same as those used in the $1.27-\mathrm{cm}-10$ ng $(0.500-$ in.) specimens, and matrix type $c$ is General Atomic Company's proprietary matrix. The specimens were injected at $180^{\circ} \mathrm{C}$ and $5.54 \mathrm{MPa}$ (800 psi) except for those containing unannealed fertile batches $M$ and $N$, which were injected at 4.16 MPa (600 psi). Eight fuel rods of matrix type a were carbonized in a bed of $\mathrm{Al}_{2} \mathrm{O}_{3}$, using a heating rate of $6^{\circ} \mathrm{C} / \mathrm{min}$ and producing a coke yield of 18.3\%; eight rods of matrix type b were carbonized in-tube, using a heating rate of $2^{\circ} \mathrm{C} / \mathrm{min}$ and producing a coke yield of $37.1 z^{\circ}$ and eight rods of matrix type $c$ were carbonized in-tube, using a heating rate of $11.5^{\circ} \mathrm{C} / \mathrm{min}$ and producing a coke yield of $29.8 \%$. All 70 ORNL specimens were subjected to a final heat treatment at $1800^{\circ} \mathrm{C}$ in argon for $30 \mathrm{~min}$. The fissile and fertile particle types and the matrix type used, along with the total weights of $235 \mathrm{U}$ and ${ }^{232} \mathrm{Th}$ contained in each rod in specimen holders $A$ and $B$, are presented in Appendix $B$.

\section{DESIGN ANALYSIS}

This chapter is divided into two parts: (1) the thermal analysis. to determine the outside diameter of each of the specimen holders and the linear heat rate necessary to maintain the desired fuel centerline temperature, and (2) the neutronic analysis to determine the ${ }^{235} \mathrm{U}$ and 232 Th loadings.

\subsection{Thermal Analysis}

The thermal analysis was aimed at determining the outside diameter of the specimen holders and the linear heat rates necessary to maintain the desircd maximum fuel centerline temperatures throughout the life of the capsule. During the conceptual design stage, it was decided that the linear heat rate of all fuel rods should be about $16.4 \mathrm{~kW} / \mathrm{m}(5.0 \mathrm{~kW} / \mathrm{ft})$ and the fuel loadings should be varied along the length of the capsule in an effort to flatten the temperature and power gradients that a single fuel loading would produce. 
The first step in the thermal analysis was to perform a three-dimensional analysis of each of the fuel specimen holders at beginning-of-life (BOL) conditions. The HEATING3 code, 1 which was used for this analysis, allows the incorporation of the axial-dependent gamma heating and thermal neutron flux (fission heating) profiles as well as temperature-dependent material thermal conductivities. An iterative process was used to determine the outside diameter of the graphite fuel specimen holders and the peak linear heat rate of each of the eight fuel loadings. The relative location of each of the fuel loadings is shown in Fig. 5.

In Figs. 7 through $y$, the predicted BOL axial temperature profiles through the fuel centerline and various regions of the graphite are presented for specimen holders $A, B$, and $C$, respectively. After operation began, it was discovered that the reaction rates used to determine the end fuel loadings ( $1 \mathrm{~A}$ and $3 \mathrm{C}$ ) were incorrect. This error resulted in a higher than desired linear heat rate for these two loadings and there. fore a different temperature profile, which is shown in Figs. 7 and 9 for loadings $1 \mathrm{~A}$ and $3 \mathrm{C}$, respectively. This problem is discussed in greater detail in Chap. 6 of this report.

When the three-dimensional analyses were completed, a two-dimensional model was made of the capsule cross section at the peak temperature location in each fuel loading. These twn-dimensional modele wcre nccessary because the radiation-induced dimensional changes vary along the length of each specimen holder, producing tapered gas gaps at end-of-life (EOL). The HEATING 3 code and the three-dimensional model used initially could not handle the EOL tapered gas gaps.

The EOI analyses were based on an operating life of $9600 \mathrm{hr}$, at which time the peak damage fluence should be the desired $9 \times 10^{21}$ neutrons $/ \mathrm{cm}^{2}$ $(E>0.18 \mathrm{MeV})$. With the use of an axial damage flux profile, ${ }^{2}$ the appropriate fluence was determined for each of the two-dimensional models. The thermal conductivity and dimensional change data for both the fuel rods and graphite holders at EOL were determined from the references listed in Table 4. 


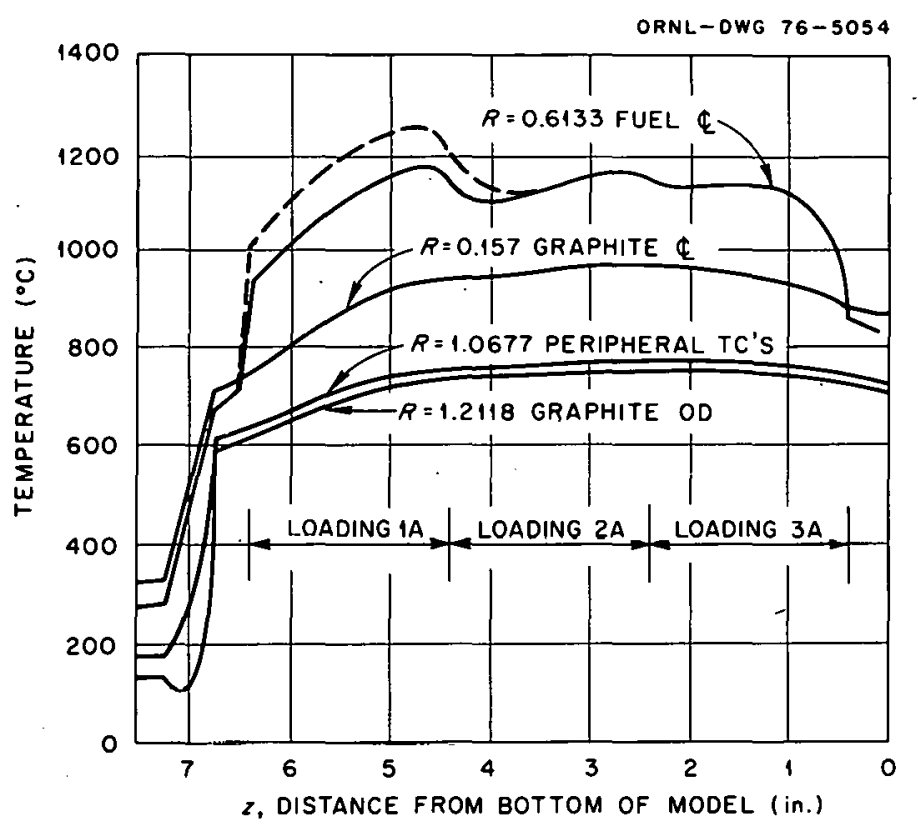

Fig. 7. Axial temperature profiles calculated by the HEATING3 program for OF-2 specimen holder $A$ at beginning of life. Solld lines represent design conditions; dashed line represents fuel centerline temperature $(1 \mathrm{in} .=2.54 \mathrm{~cm}$ ).

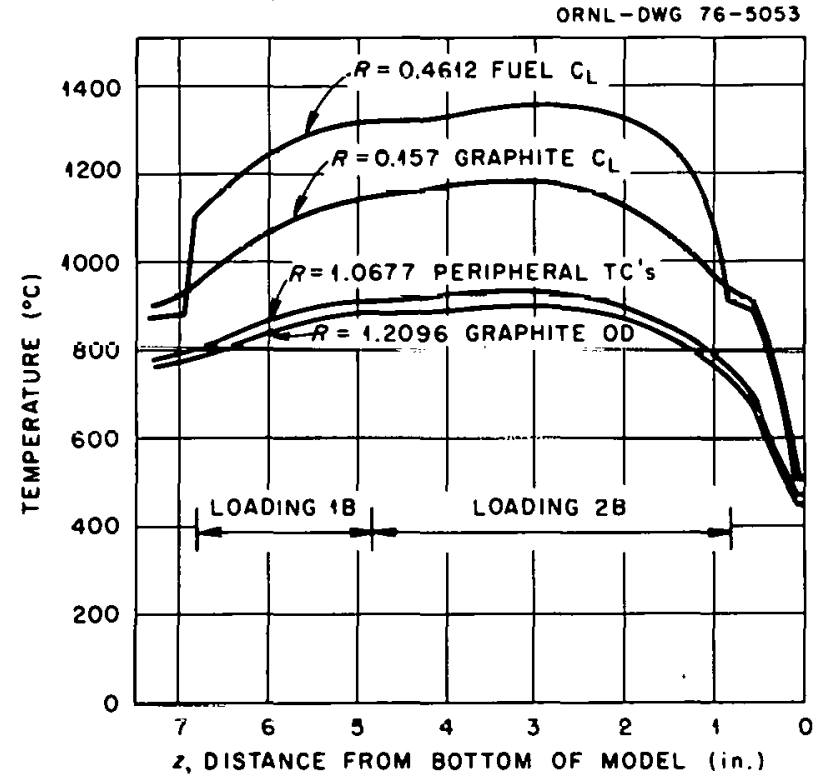

Fig. 8. Axial temperature profiles calculated by the HEATING3 program for OF-2 specimen holder $B$ at beginning of life ( 1 in. $=2.54 \mathrm{~cm}$ ). 


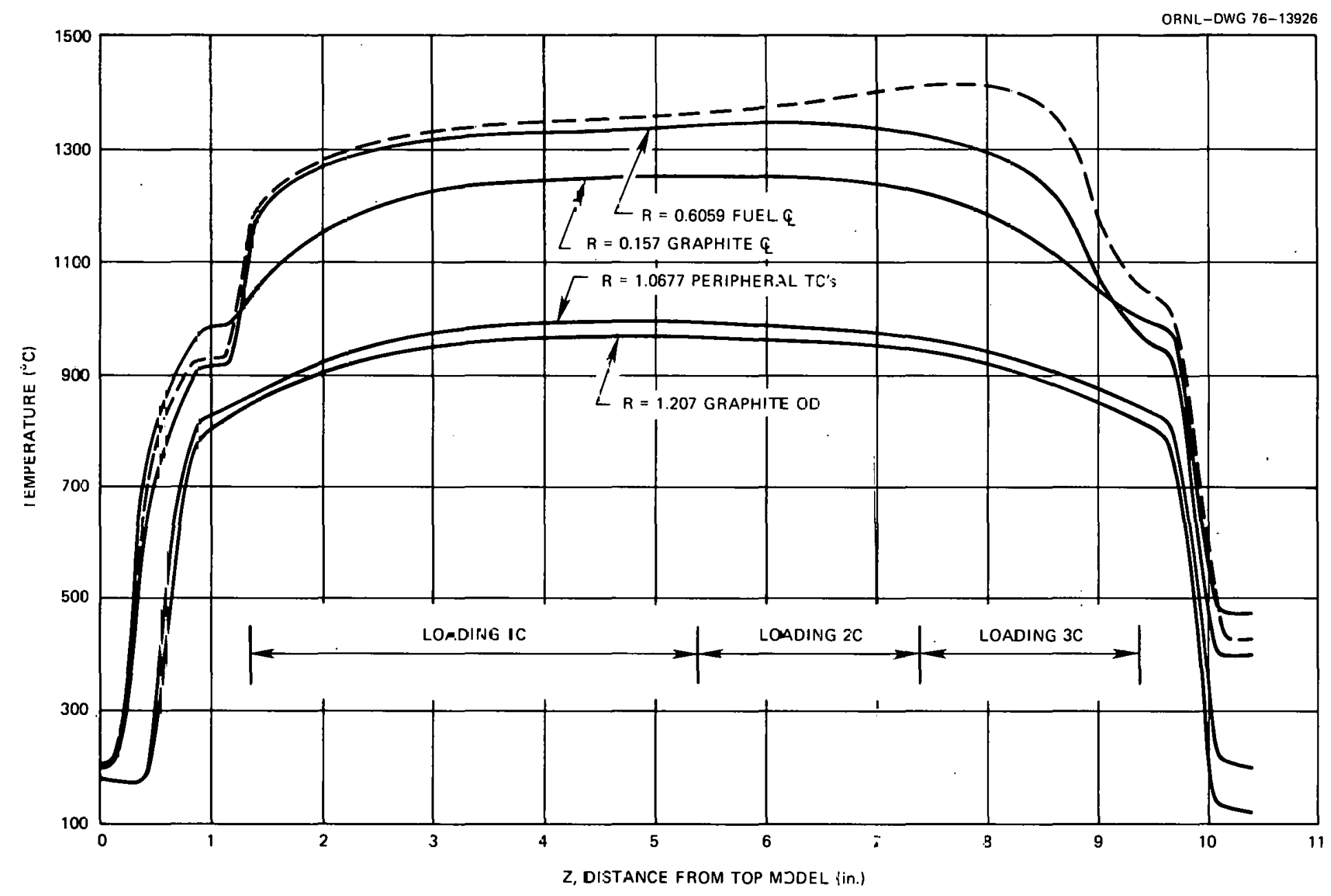

Fig. G. Axial temperature profiles calculated' by the HEATING 3 program for OF-2 specimen hclder $\mathrm{C}$ at jeginning of life. Solid lines represent design conditions; dashed line represents fuel zenterline temperature $(1$ in. $=2.54 \mathrm{~cm})$. 
Table 4. References used to determine various parameters at EOL conditions in capsule OF-2

\begin{tabular}{|c|c|}
\hline Parameter & Reference \\
\hline $\begin{array}{l}\mathrm{H}-451 \text { graphite thermal } \\
\text { conductivity }\end{array}$ & $\begin{array}{l}\text { R. J. Price, Review of the Thermal Conduc- } \\
\text { tivity of Nuclear Grophite Under HTGR Con- } \\
\text { ditions, GA-A12615, pp. 60-61 (Sept. 7, } \\
\text { 1973) }\end{array}$ \\
\hline Fuel thermal conductivity & $\begin{array}{l}\text { W. R. Johnson, Thermai Conductivity of Large } \\
\text { HTGR Fuel Rods, GA-Al2910, pp. 21-23 (Mar. } \\
\text { 15, 1974) }\end{array}$ \\
\hline $\begin{array}{l}\text { H- } 451 \text { graphite dimen- } \\
\text { sional change and ther- } \\
\text { mal expansivity }\end{array}$ & $\begin{array}{l}\text { R. J. Price and L. A. Beavan, Final Report } \\
\text { on Grophite Irradiation Test OG-1, } \\
\text { GA-Al3089 (Aug. 1, 1974) }\end{array}$ \\
\hline $\begin{array}{l}\text { Fuel rod dimensional } \\
\text { change (holders } A \text { and } B \text { ) }\end{array}$ & $\begin{array}{l}\text { Personal communication with } \mathrm{E} \text {. L. Long, Jr., } \\
\text { PIE data from HRB-8 Triso-Biso fuel rods }\end{array}$ \\
\hline $\begin{array}{l}\text { Fuel rod dimensional } \\
\text { change (holder } \mathrm{C} \text { ) }\end{array}$ & $\begin{array}{l}\text { Personal communication with } J \text { M Robbins, } \\
\text { PIE data from HT- } 24 \text { and }-25\end{array}$ \\
\hline
\end{tabular}

After the EOL geometry was determined for each of the 2-D models, an iteration process was again used to find the linear heat rate necessary to maintain the design fuel centerline temperature. A summary of $\mathrm{BOL}$ and EOL fission linear heat rates, heat transfer gaps, and maximum temperatures for capsule OF-2 is presented in Table 5.

\subsection{Neutronic Analysis}

The ${ }^{235} \mathrm{U}$ and ${ }^{232} \mathrm{Th}$ loadings were calculated from the total reaction rates and neutron fluxes provided ${ }^{2}$ for the E-7 position of the ORR core. The $235 \mathrm{U}$ loadings were calculated from the required BOL linear heat rates determined in the three-dimensional thermal analysis. The FABGEN code ${ }^{3}$ was used in an iterative process to determine the $232 \mathrm{Th}$ loading necessary to produce EOL linear heat rates to maintain the design fuel centerline temperatures as determined by the two-dimensional thermal analyses. The resultant fuel loadings are presented in Table 6 . 
Table 5. Summary of BOL and FOL fission powers, heat transfer zaps, and maximum temperatures for capsule $\mathrm{OF}-2$

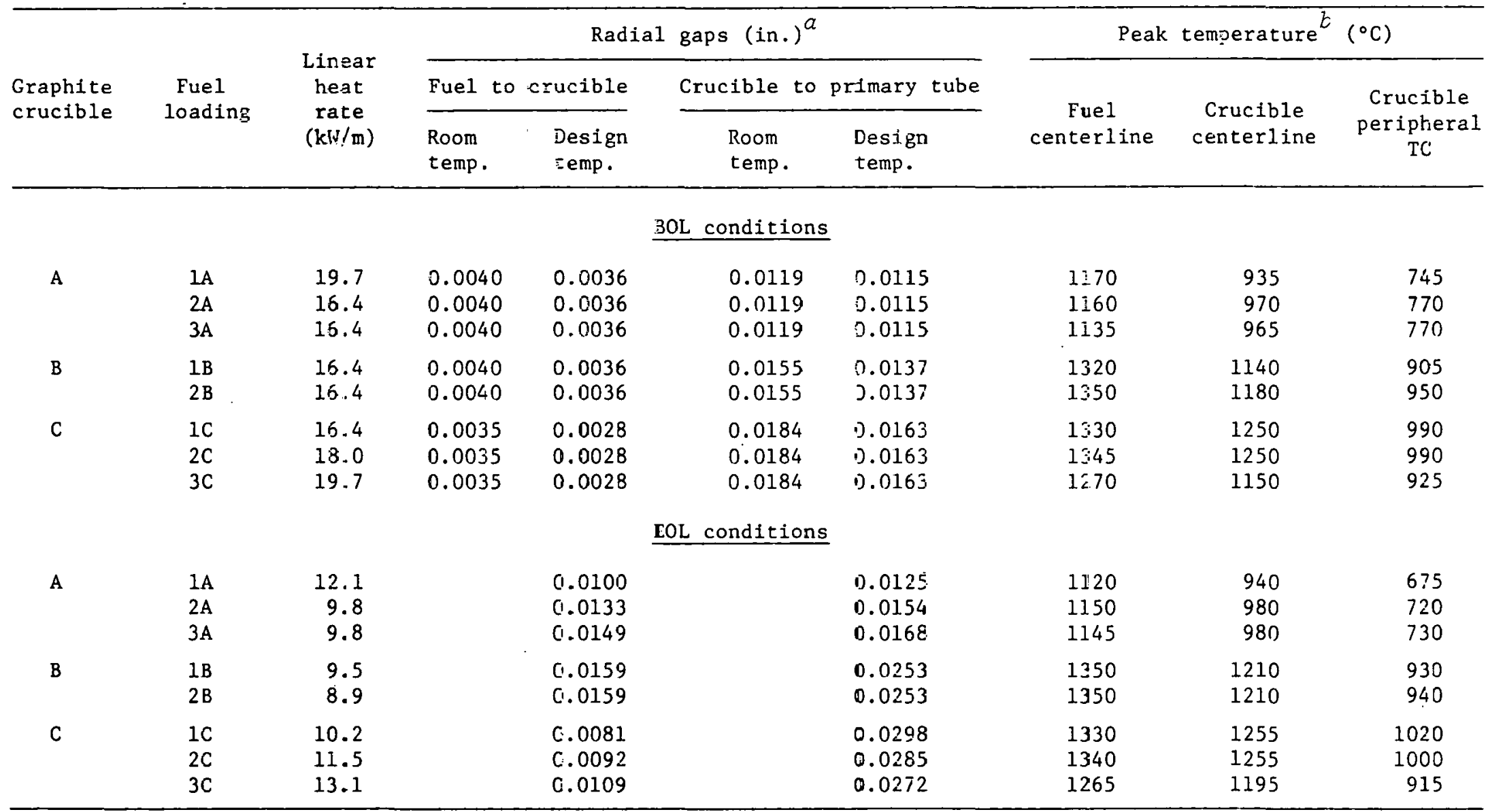

$a_{1}$ in. $=25.4 \mathrm{~mm}$.

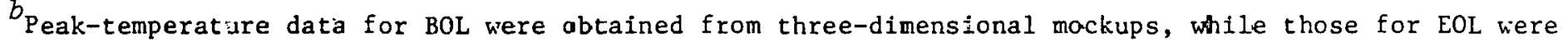
obtained from two-cimensional mockups. 
Table 6. Design fuel loadings

for capsule $\mathrm{OF}-2$

\begin{tabular}{cccc}
\hline \multirow{2}{*}{$\begin{array}{c}\text { Specimen } \\
\text { holder }\end{array}$} & $\begin{array}{c}\text { Loading } \\
\text { No. }\end{array}$ & \multicolumn{2}{c}{ Loading (g/in.) } \\
\cline { 3 - 4 } & IA & 0.238 & 3.98 \\
A & 2A & 0.135 & 2.61 \\
& 3A & 0.106 & 2.19 \\
B & 1B & 0.0815 & 1.53 \\
& 2B & 0.0691 & 1.26 \\
C & IC & 0.0669 & 1.39 \\
& 2C & 0.0795 & 1.73 \\
& 3C & 0.182 & 3.95 \\
\hline
\end{tabular}

\section{EXPERIMENTAL ASSEMBLY FABRICATION}

A detailed description of the experimental assembly fabrication procedure is presented in Engineering Document Q-11552-RB-10-S-0. A general description of the fabrication process is given below.

The copper bulkhead separating cells 1 and 2 was brazed into the primary containment vessel, and the thermocouples, gas lines, and guide tubes were brazed into the primary containment end caps. The Johnson noise thermometers and the Pt-Mo thermocouples were brazed into their respective quide tubes. The components of each cell were then loaded on their respective primary bulkhead subassemblies, and the primary containment vessel was slid over the cell components and welded to the primary bulkhead. The internal components of cells 1 and 2 are shown in Figs. 10 and 11, respectively.

The gas lines and thermocouple leads from the bottom cell were bent into position, and the secondary containment vessel was slid over the primary vessel. As this was being done, the leads and gas lines were fed 


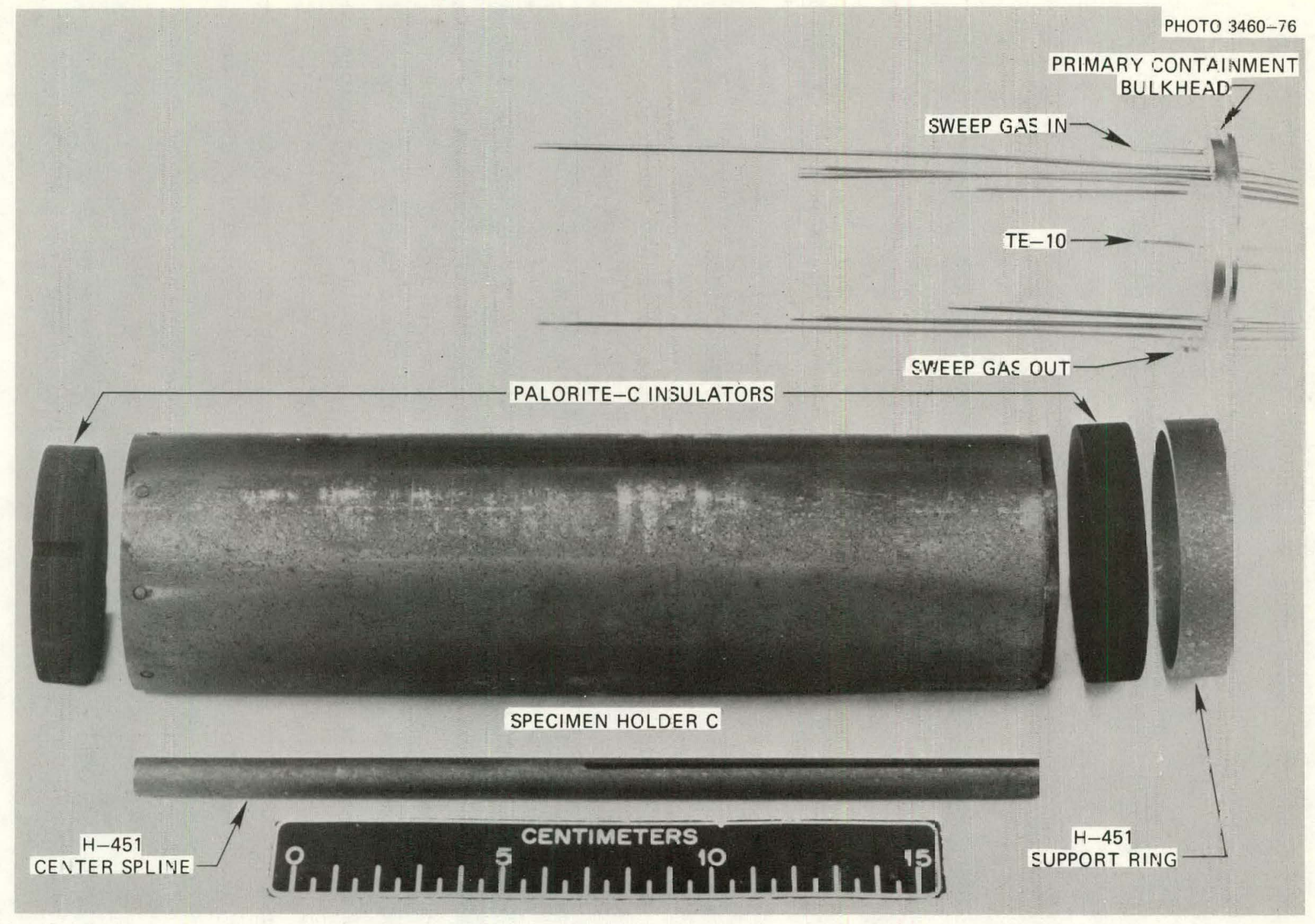

Fig. 10. Components of cell 1 in cassule $\mathrm{OF}-2$. 


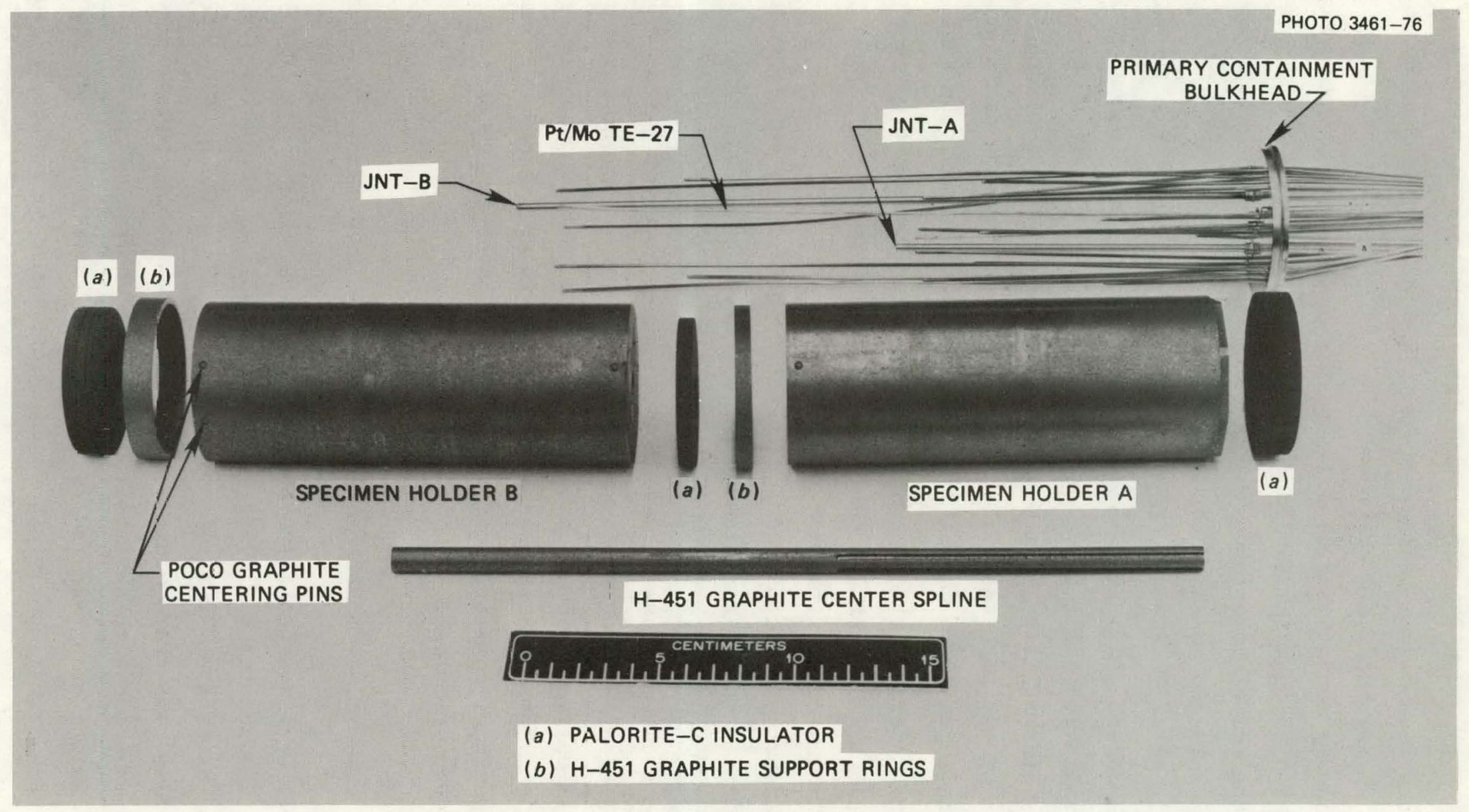

Fig. 11. Components of cell 2 in capsule $\mathrm{OF}-2$. 
through the 1.27-Cm-OD (0.50-in.) stainless steel tube that carried them back into the secondary vessel above the primary bulkhead for the top cell. Next, an approximately 6l-cm-long (2.0-ft) adapter section was welded to the secondary containment vessel, and the gas lines and thermocouple leads were fed through the secondary containment bulkhead, which was then welded to the adapter section. The gas lines and thermocouple leads were then silver soldered to the secondary bulkhead.

At this point in the assembly, it was requested that the Johnson noise thermometers (JNT) be removed because of problems discovered during the postirradiation examination of HTGR-HFIR capsule HRB-10, 4 which was in proqress at that time. The decision to remove the JNTs was based on recognition of two problems: (1) the Mo-Re sheath outside diameter was too large to accommodate the differential swelling between the fuel rods and graphite specimen holders; and (2) there was a possibility of a chemical reaction occurring between the Mo-Re sheath and the carboncoated fuel causing fuel failure.

The sensors were recovered intact after three holes were made in the completed secondary containment. These three holes are shown in Fig. 12 along with the sealed guide tubes and patches used to cover the holes. The recovered sensors were used in out-of-reactor tests to explore parallel processing of noise voltage and noise current signals and the chemical and thermal stability of the Pt-Mo thermocouples.

After the JNTs were removed and the holes in the secondary containment were patched, completion of the lead pipe assembly proceeded without any unusual problems.

\section{INITIAL OPERATION}

Capsule OF-2 was installed in the ORR during the week of June 16 to 20, 1975. The reactor was started up on June 21 , and the sweep gas to both cells was kept at $100 \%$ helium until June 23. While at $100 \%$ helium sweep gas flow, the thermocouples measuring the graphite periphery were indicating very close to expected temperatures (below design values) for all fuel loadings except $\mathrm{IA}$ and $3 \mathrm{C}$. Peripheral temperatures at loadings $1 \mathrm{~A}$ and $\mathrm{CC}$ were significantly higher than expected. At the beginning of 


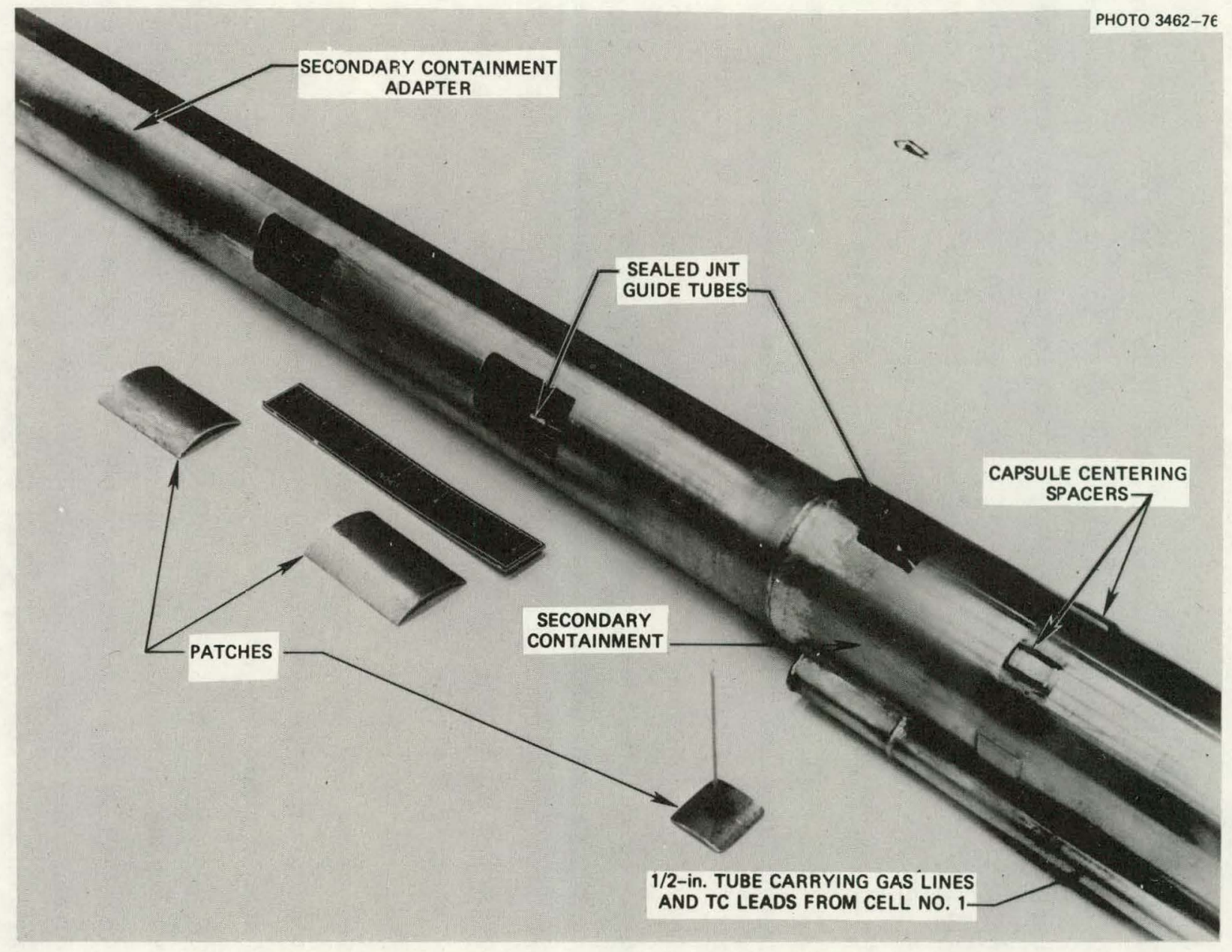

Fig. 12. Removal of Johnson noise thermometers (JNTs) from the oF-2 capsule ( 1 in. $=2.54 \mathrm{~cm}$ ). 
a fuel cycle, the temperature of fuel loading $1 \mathrm{~A}$, which is located at the top of the capsule, was anticipated to be lower than design temperature. This was based on the fact that at the beginning of a fuel cycle the flux profile is peaked toward the bottom of the reactor core, while the operating temperatures were calculated with a time-averaged flux profile.

On June 23, after having operated with $100 \%$ helium flow for about 60 $\mathrm{hr}$, neon was added to the sweep gas in an effort to obtain the desired operating temperatures. The amount of neon added to cell 1 was less than the design value because of the high peripheral graphite temperatures in loading 3C. In cell 2, the sweep gas mixture was set close to the design values: $60 \%$ helium and $40 \%$ neon, with good agreement between thermocouple readings and predicted temperatures. The operating temperature of loading $1 \mathrm{~A}$ was again higher than anticipated for the same reasons described above.

An investigation of the higher temperatures at the two end fuel loadings revealed that the design information that was used to determine fuel loadings $\mathrm{IA}$ and $3 \mathrm{C}$ was incorrect. It was found that the reaction rates used to calculate fuel loadings at the capsule ends were actually higher than the design values. When the corrected reaction rates and the as-built fuel loadings were used, it was found that loadings $1 \mathrm{~A}$ and $3 \mathrm{C}$ were operating at linear heat rates about $20 \%$ higher than desired.

A new thermal analysis was initiated to determine the effect of this increased heat-generation rate and to compare calculated and observed temperatures after $175 \mathrm{hr}$ of irradiation. The 175-hr time was chosen because it occurred approximately halfway through the first ORR fuel cycle and should therefore reflect typical time-averaged operating conditions for an entire reactor fuel cycle. After $175 \mathrm{hr}$ of irradiation, the maximum damage fluence in the fuel specimen holders was $2.5 \times 10^{20}$ neutrons $/ \mathrm{cm}^{2}$ ( $\mathrm{E}>0.18 \mathrm{MeV}$ ), which is not high enough to cause any significant dimensional changes but is high enough to cause snme change in the thermal conductivity of the H-45l graphite fuel specimen holders. Two analyses were performed; the first utilized the calculated thermal conductivity of graphite as presented by Price, ${ }^{5}$ and the second was performed using $85 \%$ of the thermal conductivity presented by Price. A comparison of the second analysis with observed temperatures is presented in Table 7. 
Table 7. Comparison of calculated and observed temperatures in capsule $0 \mathrm{~F}-2$ after $175 \mathrm{hr}$ irradiation

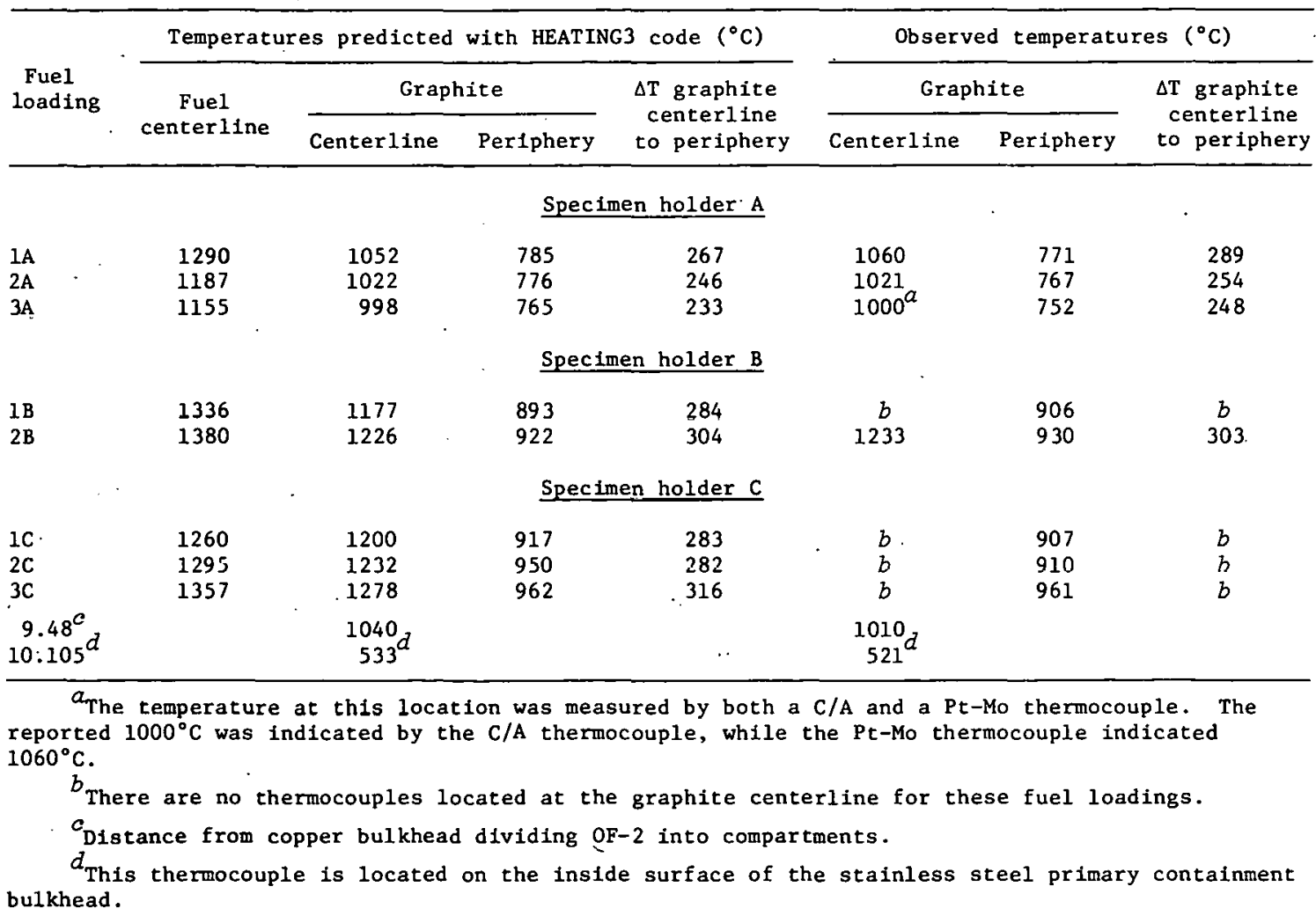

The first case produced very good agreement with observed graphite periphery temperatures but poor agreement with observed graphite centerline temperatures. In the second case, where the graphite thermal conductivity was reduced by 158, agreement with observed graphite centerline temperatures was very good without significantly changing the graphite periphery temperature agreement. Perhaps a more accurate comparison between calculated and observed temperatures is the $\Delta T$ between the graphite centerline and the periphery. Table 7 shows that this $\Delta T$ agreement between the second case and observed temperatures is no worse than $8 \%$.

During the thermal analysis, it was found that the Pt-Mo thermocouple used to measure the graphite centerline temperature of fuel loading $3 \mathrm{~A}$ was indicating a temperature approximately $60^{\circ} \mathrm{C}$ higher than that calculated. This difference between the Pt-Mo and $C / A$ thermocouples at this location was noted earlier. The real temperature was assumed to be an average of the two. However, as can be seen in Table 7, the C/A ther- 
mocouple agrees very well with the calculated temperatures and the calculated axial temperature profile. The other Pt-Mo thermocouple which measures the graphite centerline temperature in fuel loading $2 \mathrm{~B}$ agrees very well with the predicted temperature.

As a result of the higher heat-generation rate in fuel loading $1 \mathrm{~A}$, temperature control in cell 2 became more complex. At the beginning of a reactor fuel cycle, the maximum fuel centerline temperature of specimen holder $\mathrm{B}$ can be brought to $1350^{\circ} \mathrm{C}$ with the maximum fuel centerline temperature of specimen holder $A$ at about $1150^{\circ} \mathrm{C}$. As the reactor fuel cycle progresses and the control rods are withdrawn, the fuel centerline temperature of holder $A$ continues to rise and, depending on the length of the cycle, could also reach $1350^{\circ} \mathrm{C}$. A decision was made to allow the fuel centerline temperature of holder $A$ to reach a maximum of $1200^{\circ} \mathrm{C}$ and then adjust the sweep gas mixture to maintain holder $A$ at $1200^{\circ} \mathrm{C}$, thus causing holder $B$ temperatures to decrease.

The higher heat-generation rate of fuel loading 36 hac alco forccd a compromise in the operating temperatures in cell 1 . The maximum fuel centerline temperature in this cell occurs in loading $3 \mathrm{C}$, and it is maintained at $1350^{\circ} \mathrm{C}$, causing loadings $\mathrm{IC}$ and $2 \mathrm{C}$ to operate at significantly lower than design temperatures.

Sweep gas samples are taken once per week to determine the releaseto-birth rate ratios $(R / B)$ for five fission gas isotopes. The results of these analyses through the first cycle of operation are precented in Table 8. Nute that the first sample taken in each cell was with the sweep gas at $100 \%$ helium, and therefore operating temperatures are significantly lower for these samples.

A complete operating history for all thermocouples during the first cycle of operation is presented in Appendix $c$. 
Table 8. R/B ratios for the first cycle of operation of capsule $0 F-2$

\begin{tabular}{|c|c|c|c|c|c|c|c|c|c|c|c|c|}
\hline \multirow{2}{*}{$\begin{array}{l}\text { Cell } \\
\text { No. }\end{array}$} & \multirow{2}{*}{$\begin{array}{c}\text { Sample } \\
\text { No. }\end{array}$} & \multirow{2}{*}{ Date } & \multirow{2}{*}{ Time } & \multirow{2}{*}{$\begin{array}{l}\text { Operating } \\
\text { time } \\
\text { (hr) }\end{array}$} & \multicolumn{3}{|c|}{$\begin{array}{l}\text { Estimated maximum fuel } \\
\text { centerline temperature }\left({ }^{\circ} \mathrm{C}\right)\end{array}$} & \multicolumn{5}{|c|}{$\mathrm{R} / \mathrm{B}$ ratios $\left(\times 10^{-5}\right)$} \\
\hline & & & & & $\begin{array}{l}\text { Holder } \\
\text { A }\end{array}$ & $\begin{array}{l}\text { Holder } \\
\text { B }\end{array}$ & $\begin{array}{l}\text { Holder } \\
\quad \mathrm{C}\end{array}$ & $85^{\mathrm{m}} \mathrm{Kr}$ & ${ }^{87} \mathrm{Kr}$ & ${ }^{8} 8_{\mathrm{Kr}}$ & $133 \mathrm{Xe}$ & $135 \mathrm{Xe}$ \\
\hline 1 & $\begin{array}{l}1-A-1 \\
1-A-3 \\
1-A-5 \\
1-A-7 \\
1-A-9 \\
1-A-11 \\
1-A-13\end{array}$ & $\begin{array}{l}6-23-75 \\
6-24-75 \\
7-2-75 \\
7-9-75 \\
7-18-75 \\
7-25-75 \\
8-6-75\end{array}$ & $\begin{array}{l}0949 \\
1112 \\
1009 \\
1330 \\
1235 \\
0855 \\
1035\end{array}$ & $\begin{array}{c}53.7 \\
79.1 \\
270 \\
436 \\
652 \\
811 \\
1095\end{array}$ & & & $\begin{array}{l}1230 \\
1350 \\
1340 \\
1350 \\
1340 \\
1360 \\
1350\end{array}$ & $\begin{array}{l}1.0 \\
2.8 \\
1.7 \\
3.1 \\
1.9 \\
3.0 \\
2.2\end{array}$ & $\begin{array}{l}0.63 \\
1.9 \\
0.60 \\
1.0 \\
1.4 \\
0.88 \\
1.2\end{array}$ & $\begin{array}{l}0.50 \\
1.7 \\
1.0 \\
0.71 \\
1.1 \\
1.0\end{array}$ & $\begin{array}{l}1.2 \\
5.4 \\
2.2 \\
3.2 \\
3.1 \\
4.3 \\
5.1\end{array}$ & $\begin{array}{l}0.35 \\
0.76 \\
0.75 \\
0.60 \\
0.75 \\
0.62 \\
0.19\end{array}$ \\
\hline 2 & $\begin{array}{l}2-\dot{A}-2 \\
2-A-4 \\
2-A-6 \\
2-A-8 \\
2-A-10 \\
2-A-12 \\
2-A-14\end{array}$ & $\begin{array}{l}6-23-75 \\
6-24-75 \\
7-2-75 \\
7-9-75 \\
7-18-75 \\
7-25-75 \\
8-6-75\end{array}$ & $\begin{array}{l}100= \\
1127 \\
1020 \\
134= \\
1252 \\
0906 \\
1040\end{array}$ & $\begin{array}{r}53.9 \\
79.3 \\
270 \\
436 \\
652 \\
811 \\
1095\end{array}$ & $\begin{array}{r}990 \\
1170 \\
1280 \\
1190 \\
1170 \\
1225 \\
1210\end{array}$ & $\begin{array}{l}1190 \\
1350 \\
1360 \\
1340 \\
1350 \\
1340 \\
1300\end{array}$ & & $\begin{array}{l}1.1 \\
15 \\
21 \\
10 \\
9.8 \\
7.5 \\
8.8\end{array}$ & $\begin{array}{l}0.46 \\
2.0 \\
7.7 \\
4.4 \\
4.1 \\
5.0 \\
4.0\end{array}$ & $\begin{array}{l}0.35 \\
3.2 \\
8.9 \\
5.8 \\
2.3 \\
5.7 \\
4.7\end{array}$ & $\begin{array}{l}1.3 \\
33 \\
57 \\
57 \\
36 \\
56 \\
44\end{array}$ & $\begin{array}{l}0.42 \\
1.4 \\
3.9 \\
1.9 \\
1.1 \\
3.1 \\
1.2\end{array}$ \\
\hline
\end{tabular}




\section{ACKNOWLEDGMENTS}

The authors wish to acknowledge the efforts of many people who made significant contributions to the planning and implementation of this experiment. W. P. Eatherly, F. J. Homan, R. L. Beatty, R. A. Bradley, W. J. Lackey, Jr., and E. L. Long, Jr., of the Metals and Ceramics Division; T. B. Lindemer of the Chemical Technology Division; and J. A. Conlin of the Reactor Division participated in the planning and design of the experiment. A. J. Caputo, J M Robbins, J. C. McLaughlin, and D. E. Rossin of the Metals and Ceramics Division fabricated and characterized the slug-injected fuel rods. The fissile and fertile particles were coated and characterized by R. L. Beatty, W. J. Lackey, Jr., C. E. Devore, and C. Hamby, Jr., of the Metals and Ceramics Division. D. R. Johnson and $R$. $\bar{L}$. Beatty were responsible for carbonization and conversion of the fissile particles. Dosimetry for the capsule was provided by E. J. Allen, H. T. Kerr, and D. L. Reed of the Reactor Division. Thermometry for the capsule was provided by $R$. L. Shepard of the Instrumentation and Controls Division. Fuel specimens from Los Alamos Scientific Laboratory were provided by $P$. Wagner.

\section{REFERENCES}

1. W. D. Turner and M. Simon-Tov, HEATINC3 - An IBM/360 Hoat Conduotion Program, ORNL/TM-3208 (February 1971).

2. H. T. Kerr, personal communication.

3. H. C. Roland, FABGEN - A Transient Power Generation and Isotope Bulk Rate Calculation, ORNL/TM-4750 (April 1975).

4. F. J. Homan et al., "Capsules HRB-9 and -10," HTGR Base Program Progress Report for Period Jan. 1, 1974 through June 30, 1975, ORNL-5108 (in preparation).

5. R. J. Price, Review of the Thermal Conductivity of Nuclear Graphite Under HTGR Conditions, GA-Al2615, pp. 60-61 (Sept. 7, 1973). 
Appendix A

OF-2 FLUX MONITOR WEIGHTS 
THIS PAGE

\section{WAS INTENTIONALLY LEFT BLANK}


Table A-1. OF-2 Flux monitor weights

\begin{tabular}{|c|c|c|c|c|c|}
\hline $\begin{array}{c}\text { Monitor } \\
\text { package } \\
\text { No. }\end{array}$ & $\begin{array}{l}\text { Hole } \\
\text { No. }\end{array}$ & $\begin{array}{l}\text { Position } \\
\text { No. }\end{array}$ & $\begin{array}{l}\mathrm{V}-\mathrm{Co} \\
\text { (mg) }\end{array}$ & $\begin{array}{l}\text { 5-mil } \mathrm{Fe} \\
\text { (mg) }\end{array}$ & $\underset{(\mathrm{mg})}{20 \mathrm{mil}} \mathrm{Fe}$ \\
\hline 1 & 1 & 1 & 4.016 & 2.643 & 8.880 \\
\hline 2 & 1 & 2 & 3.896 & 2.590 & 10.014 \\
\hline 3 & 1 & 3 & 3.686 & 2.634 & 11.923 \\
\hline 4 & 1 & 4 & 4.026 & 2.638 & 12.610 \\
\hline 5 & 1 & 5 & 3.657 & 2.614 & 1.1 .530 \\
\hline 6 & 2 & 1 & 3.888 & 2.634 & 11.145 \\
\hline 7 & 2 & 2 & 3.544 & 2.565 & 10.586 \\
\hline 8 & 2 & 3 & 3.531 & 2.494 & 10.805 \\
\hline 9 & 3 & 1 & 3.792 & 2.654 & 10.240 \\
\hline 10 & 3 & 2 & 3.866 & 2.649 & 10.245 \\
\hline 11 & 3 & 3 & 4.002 & 2.466 & 8.891 \\
\hline 12 & 4 & 1 & 3.379 & 2.610 & 9.778 \\
\hline 13 & 4 & 2 & 3.465 & 2.645 & 10.426 \\
\hline 14 & 4 & 3 & 3.855 & 2.618 & 8.059 \\
\hline 15 & 5 & 1 & 3.635 & 2.674 & 10.309 \\
\hline 16 & 5 & 2 & 3.602 & 2.627 & 9.747 \\
\hline 17 & 5 & 3 & 3.505 & 2.653 & 10.270 \\
\hline 18 & 6 & 4 & 4.817 & 2.627 & 8.758 \\
\hline 19 & 6 & 5 & 3.827 & 2.617 & 10.585 \\
\hline 20. & 6 & 6 & 3.975 & 2.635 & 10.580 \\
\hline 21 & 7 & 4 & 4.417 & 2.633 & 9.227 \\
\hline 22 & 7 & 5 & 3.456 & 2.612 & 8.760 \\
\hline 23 & 7 & 6 & 3.804 & 2.616 & 10.247 \\
\hline 24 & 8 & 4 & 3.199 & 2.670 & 10.310 \\
\hline 25 & 8 & 5 & 4.037 & 2.640 & 11.184 \\
\hline 26 & 8 & 6 & 3.976 & 2.472 & 9.919 \\
\hline 27 & 9 & 4 & 4.691 & 2.641 & 12.101 \\
\hline 28 & 9 & 5 & 3.400 & 2.533 & 12.426 \\
\hline 29 & 9 & 6 & 3.986 & 2.600 & 9.892 \\
\hline 30 & 10 & 7 & 3.654 & 2.630 & 9.241 \\
\hline 31 & 10 & 8 & 4.431 & 2.634 & 11.540 \\
\hline 32 & 10 & 9 & 3.771 & 2.591 & 10.822 \\
\hline
\end{tabular}


THIS PAGE

\section{WAS INTENTIONALLY LEFT BLANK}


Appendix B

DESCRIPTION OF FUEL RODS IN THE OF-2 CAPSULE 
THIS PAGE

\section{WAS INTENTIONALLY LEFT BLANK}


Table B-1. Fuel rods for OF-2 irradiation capsule

\begin{tabular}{|c|c|c|c|c|c|c|}
\hline \multirow{2}{*}{$\begin{array}{l}\text { Specimen } \alpha \\
\text { location }\end{array}$} & \multirow{2}{*}{$\begin{array}{l}\text { Length } \\
(\text { in.) } b\end{array}$} & \multicolumn{2}{|c|}{ Particle type } & \multirow{2}{*}{$\begin{array}{l}\text { Matrix } \\
\text { type }\end{array}$} & \multirow{2}{*}{$\begin{array}{l}235_{\mathrm{U}} \\
(\mathrm{g})\end{array}$} & \multirow{2}{*}{$\begin{array}{c}232 \mathrm{Th} \\
\text { (g) }\end{array}$} \\
\hline & & Fissile ${ }^{c}$ & Fertile $e^{d}$ & & & \\
\hline$A-1-1$ & 1.00 & 14 & $M$ & $\mathbf{b}$ & 0.2380 & 3.980 \\
\hline-2 & 1.00 & 13 & M & $a$ & 0.2380 & 3.980 \\
\hline-3 & 1.00 & 14 & $G$ & $a$ & 0.1350 & 2.610 \\
\hline-4 & 1.00 & 14 & G & c & 0.1350 & 2.610 \\
\hline-5 & 1.00 & 13 & $\mathrm{G}$ & $b$ & 0.1060 & 2.190 \\
\hline-6 & 1.00 & 13 & M & $\mathrm{c}$ & 0.1060 & 2.190 \\
\hline$A-2-1$ & 1.00 & 14 & $\mathbf{M}$ & a & 0.2380 & 3.980 \\
\hline-2 & 1.00 & 14 & $G$ & $\mathrm{~b}$ & 0.2380 & 3.980 \\
\hline-3 & 1.00 & 13 & M & $\mathrm{b}$ & 0.1350 & 2.610 \\
\hline-4 & 1.00 & 13 & G & $c$ & 0.1350 & 2.610 \\
\hline-5 & 1.00 & 14 & M & c & 0.1060 & 2.190 \\
\hline-6 & 1.00 & 13 & G & a & 0.1060 & 2.190 \\
\hline$A-3-1$ & 0.50 & 12 & $M$ & $\mathrm{~d}$ & 0.1190 & 1.990 \\
\hline-2 & 0.50 & 2 & $I$ & $\mathrm{~d}$ & 0.1190 & 1.990 \\
\hline-3 & 0.50 & 11 & $\mathrm{H}$ & d & 0.1190 & 1.990 \\
\hline-4 & 0.50 & 2 & G & $\mathrm{d}$ & 0.1190 & 1.990 \\
\hline-5 & 0.50 & 4 & $\mathrm{~K}$ & $\mathrm{~d}$ & 0.0675 & 1.805 \\
\hline-6 & 0.50 & 6 & $\mathrm{~J}$ & d & 0.0675 & 1.805 \\
\hline-7 & 0.50 & 8 & $\mathrm{G}$ & $d$ & 0.0675 & 1.805 \\
\hline-8 & 0.50 & 10 & $\mathrm{H}$ & $d$ & 0.0675 & 1.805 \\
\hline-9 & 0.50 & 4 & $\mathbf{I}$ & $d$ & 0.0530 & 1.095 \\
\hline-10 & 0.50 & 2 & $\mathrm{C}$ & $\mathrm{d}$ & 0.0530 & 1.095 \\
\hline-11 & 0.50 & 8 & A & $\mathrm{d}$ & 0.0530 & 1.095 \\
\hline-12 & 0.50 & 12 & B & $\mathrm{d}$ & 0.0530 & 1.095 \\
\hline$A-4-1$ & 0.50 & 9 & G & $d$ & 0.1190 . & 1.990 \\
\hline-2 & 0.50 & 1 & H & $d$ & 0.1190 & 1.990 \\
\hline-3 & 0.50 & 9 & I & $\mathrm{d}$ & 0.1190 & 1.990 \\
\hline-4 & 0.50 & 1 & $\mathrm{~J}$ & $\mathrm{~d}$ & 0.1190 & 1.990 \\
\hline-5 & 0.50 & 3 & A & $d$ & 0.0675 & 1.805 \\
\hline-6 & 0.50 & 5 & B & d & 0.0675 & 1.805 \\
\hline-7 & 0.50 & 7 & $\mathrm{C}$ & $\mathrm{d}$ & 0.0675 & 1.805 \\
\hline-8 & 0.50 & 11 & $\mathrm{D}$ & $\mathrm{d}$ & 0.0675 & 1.805 \\
\hline-9 & 0.50 & 3 & $\mathrm{E}$ & $\mathrm{d}$ & 0.0530 & 1.095 \\
\hline$=10$ & 0.50 & 1 & $F$ & ก & 0.0530 & 1. : 095 \\
\hline-11 & 0.50 & 7 & A & $d$ & 0.0530 & 1.095 \\
\hline-12 & 0.50 & LASL & LASL & LASL & 0.0530 & 1.095 \\
\hline$B-1-1$ & 1.00 & 13 & $\mathbf{M}$ & $\mathrm{b}$ & 0.0814 & 1.530 \\
\hline-2 & 1.00 & 13 & $\mathrm{G}$ & a & 0.0814 & 1.530 \\
\hline-3 & 1.00 & 13 & G & $c$ & 0.0690 & 1.260 \\
\hline-4 & 1.00 & 14 & M & $a$ & 0.0690 & 1.260 \\
\hline-5 & 1.00 & 14 & G & $\mathrm{b}$ & 0.0690 & 1.260 \\
\hline-6 & 1.00 & 14 & M & c & 0.0690 & 1.260 \\
\hline B-2-1 & 1.00 & 13 & $S$ & $\mathrm{~b}$ & 0.0814 & 1.530 \\
\hline-2 & 1.00 & 14 & $M$ & $b$ & 0.0814 & 1.530 \\
\hline-3 & 1.00 & 14 & $G$ & a & 0.0690 & 1.260 \\
\hline-4 & 1.00 & 13 & $\mathbf{M}$ & $a$ & 0.0690 & 1.260 \\
\hline-5 & 1.00 & 13 & M & c & 0.0690 & 1.260 \\
\hline-6 & 1.00 & 14 & $G$ & c & 0.0690 & 1.260 \\
\hline
\end{tabular}


Table B-1 (continued)

\begin{tabular}{|c|c|c|c|c|c|c|}
\hline \multirow{2}{*}{$\begin{array}{l}\text { Specimen } \\
\text { location }\end{array}$} & \multirow{2}{*}{$\begin{array}{l}\text { Length } \\
(\text { in.) } b\end{array}$} & \multicolumn{2}{|c|}{ Particle type } & \multirow{2}{*}{$\begin{array}{l}\text { Matrix } \\
\text { type }\end{array}$} & \multirow{2}{*}{$\begin{array}{l}23^{5} \mathrm{U} \\
(\mathrm{g})\end{array}$} & \multirow{2}{*}{$\begin{array}{c}232 \mathrm{Th} \\
(\mathrm{g})\end{array}$} \\
\hline & & Fissile $e^{c}$ & Fertile & & & \\
\hline B-3-1 & 0.50 & 12 & $\dot{\mathrm{A}}$ & d & 0.0407 & 0.765 \\
\hline-2 & 0.50 & 2 & B & $d$ & 0.0407 & 0.765 \\
\hline-3 & 0.50 & 4 & $\mathrm{C}$ & $\mathrm{d}$ & 0.0407 & .0 .765 \\
\hline-4 & 0.50 & 6 & D & $d$ & 0.0407 & 0.765 \\
\hline-5 & 0.50 & 8 & $\mathrm{E}$ & $d$ & 0.0345 & 0.630 \\
\hline-6 & 0.50 & 10 & $\mathbf{F}$ & d & 0.0345 & 0.630 \\
\hline-7 & 0.50 & 2 & L & $d$ & 0.0345 & 0.630 \\
\hline-8 & 0.50 & 4 & G & 4 & ก. 0.345 & 0.630 \\
\hline-9 & 0.50 & 3 & $\mathrm{H}$ & d & 0.0345 & 0.630 \\
\hline 10 & 0.50 & 8 & $I$ & u & 0.0343 & 0.630 \\
\hline-11 & 0.50 & 2 & $\mathrm{~J}$ & $d$ & 0.0345 & 0.630 \\
\hline-12 & 0.50 & 4 & $\mathrm{~K}$ & $\mathrm{~d}$ & 0.0345 & 0.630 \\
\hline B 41 & 0.50 & 11 & $G$ & $d$ & 0.0407 & ن. \\
\hline-2 & 0.50 & 1 & $\mathrm{H}$ & d & 0.0407 & 0.765 \\
\hline-3 & 0.50 & 3 & I & $d$ & 0.0407 & 0.765 \\
\hline-4 & 0.50 & 5 & $\mathrm{~J}$ & d & 0.0407 & 0.765 \\
\hline-5 & 0.50 & 7 & A & 4 & ก. 0345 & $\cap 63 n$ \\
\hline-6 & 0.50 & 9 & B & $d$ & 0.0345 & 0.630 \\
\hline-7 & 0.50 & 1 & C & $d$ & 0.0345 & 0.630 \\
\hline-8 & 0.50 & 3 & D & $d$ & 0.0345 & 0.630 \\
\hline-9 & 0.50 & 5 & E & d & 0.0345 & 0.630 \\
\hline-10 & 0.50 & 7 & $F$ & $d$ & 0.0345 & 0.630 \\
\hline-11 & 0.50 & 1 & A & $\mathrm{d}$ & 0.0345 & 0.630 \\
\hline-12 & 0.50 & LASL & LASL & LASL & 0.0345 & 0.630 \\
\hline$c-1-1$ & 2.00 & 13 & $\mathbf{N}$ & $c$ & 0.1330 & 2.700 \\
\hline-2 & 2.00 & 13 & I & c & 0.1338 & 2.780 \\
\hline-3 & 2.00 & 14 & $\mathbf{G}$ & c & 0.1590 & 3.460 \\
\hline-1 & 2.00 & 1.3 & 0 & $L$ & 0.3640 & 7.900 \\
\hline$a-2-1$ & 2.00 & 15 & 0 & c & 0.1338 & 2.780 \\
\hline-2 & 2.00 & 13 & $G$ & $c$ & U. 1338 & 2.180 \\
\hline-3 & 2.00 & 15 & H & $c$ & 0.1590 & 3.460 \\
\hline-4 & 2.00 & 15 & $P$ & c & 0.3640 & 7.900 \\
\hline$C-3-1$ & 2.00 & 14 & $M$ & c & 0.1338 & 2.780 \\
\hline-2 & 2.00 & 14 & $\mathrm{P}$ & c & 0.1338 & 2.780 \\
\hline-3 & 2.00 & 13 & $\mathrm{~J}$ & c & 0.1590 & 3.460 \\
\hline-4 & 2.00 & 14 & M & c & 0.3640 & 7.900 \\
\hline$(:-4-1$ & 2.00 & 15 & $\mathrm{H}$ & c & 0.1338 & 2.780 \\
\hline$\therefore \quad-2$ & 2.00 & 14 & $\mathrm{~J}$ & c & 0.1338 & 2.780 \\
\hline-3 & 2.00 & 13 & I & c & 0.1590 & 3.460 \\
\hline-4 & 2.00 & 13 & $\mathrm{~N}$ & c & 0.3640 & 7.900 \\
\hline
\end{tabular}

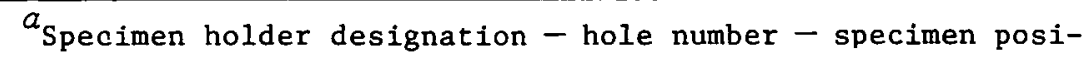
tion from top.

$b_{1}$ in. $=25.4 \mathrm{~mm}$.

- Fissile particle rype described in Table 1 of text.

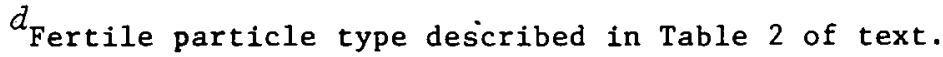

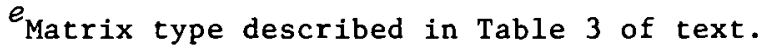


Appendix C

THERMOCOUPLE OPERATING TEMPERATURE HISTORY FOR OF-2 DURING CYCLE 126 
THIS PAGE

WAS INTENTIONALLY

LEFT BLANK 


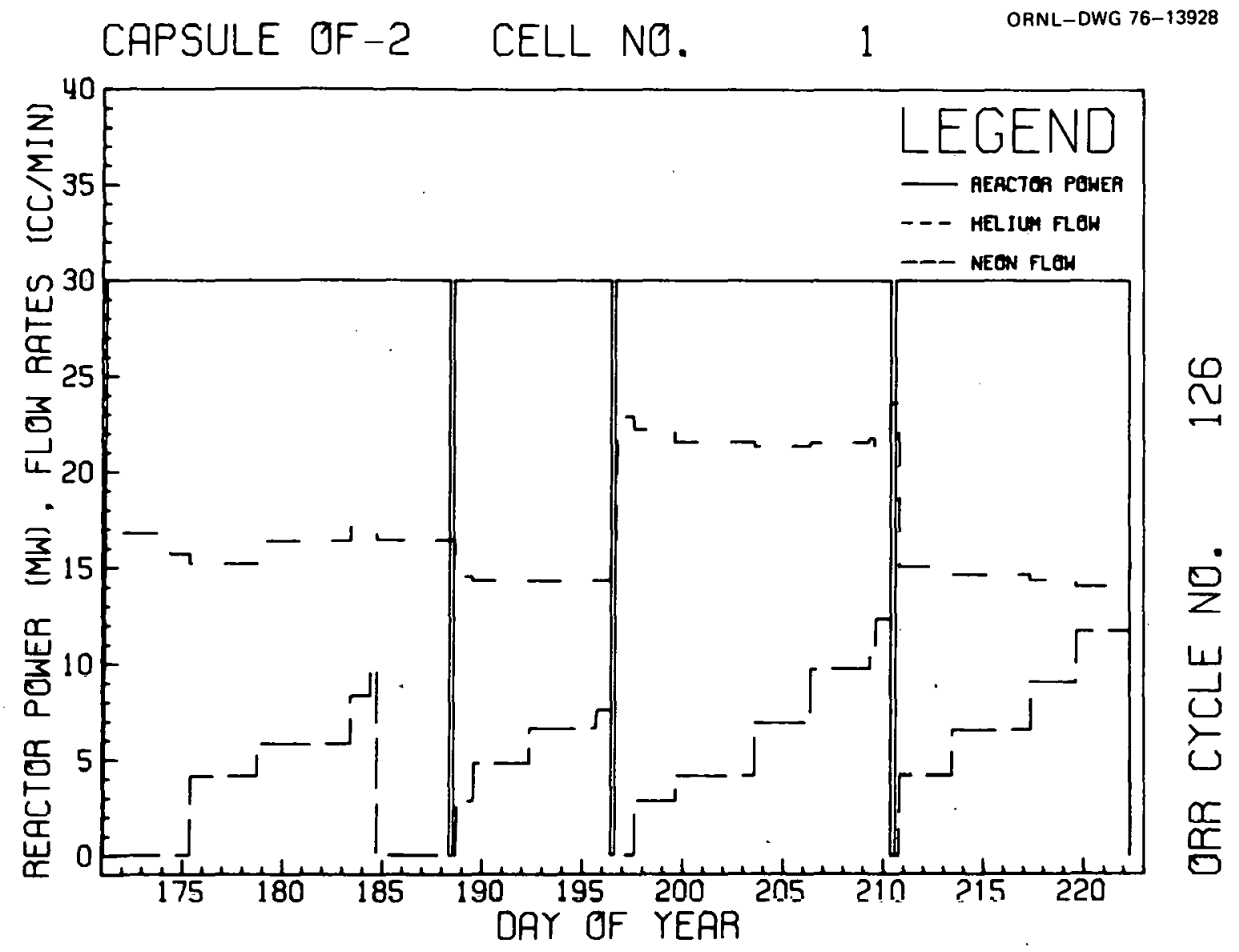




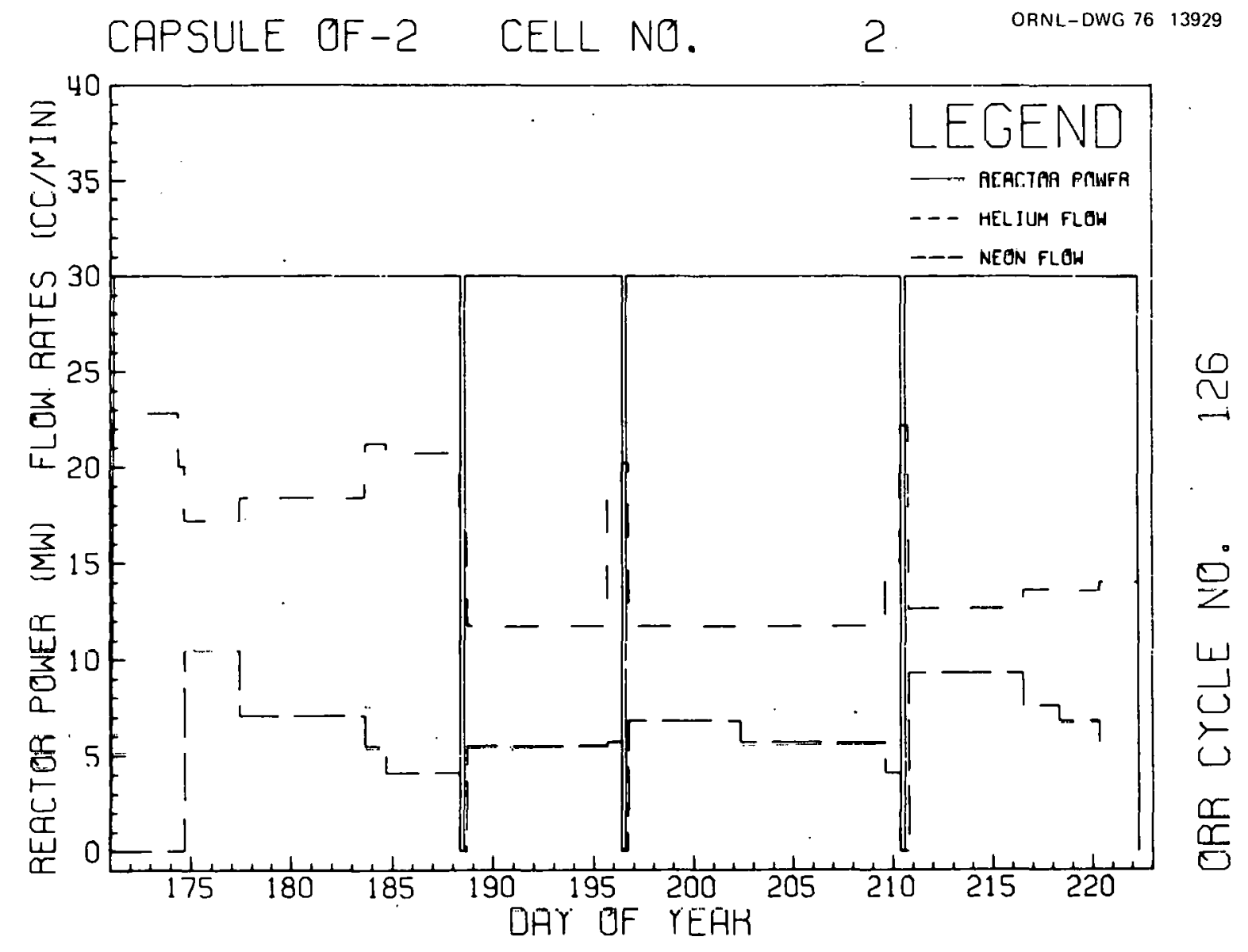




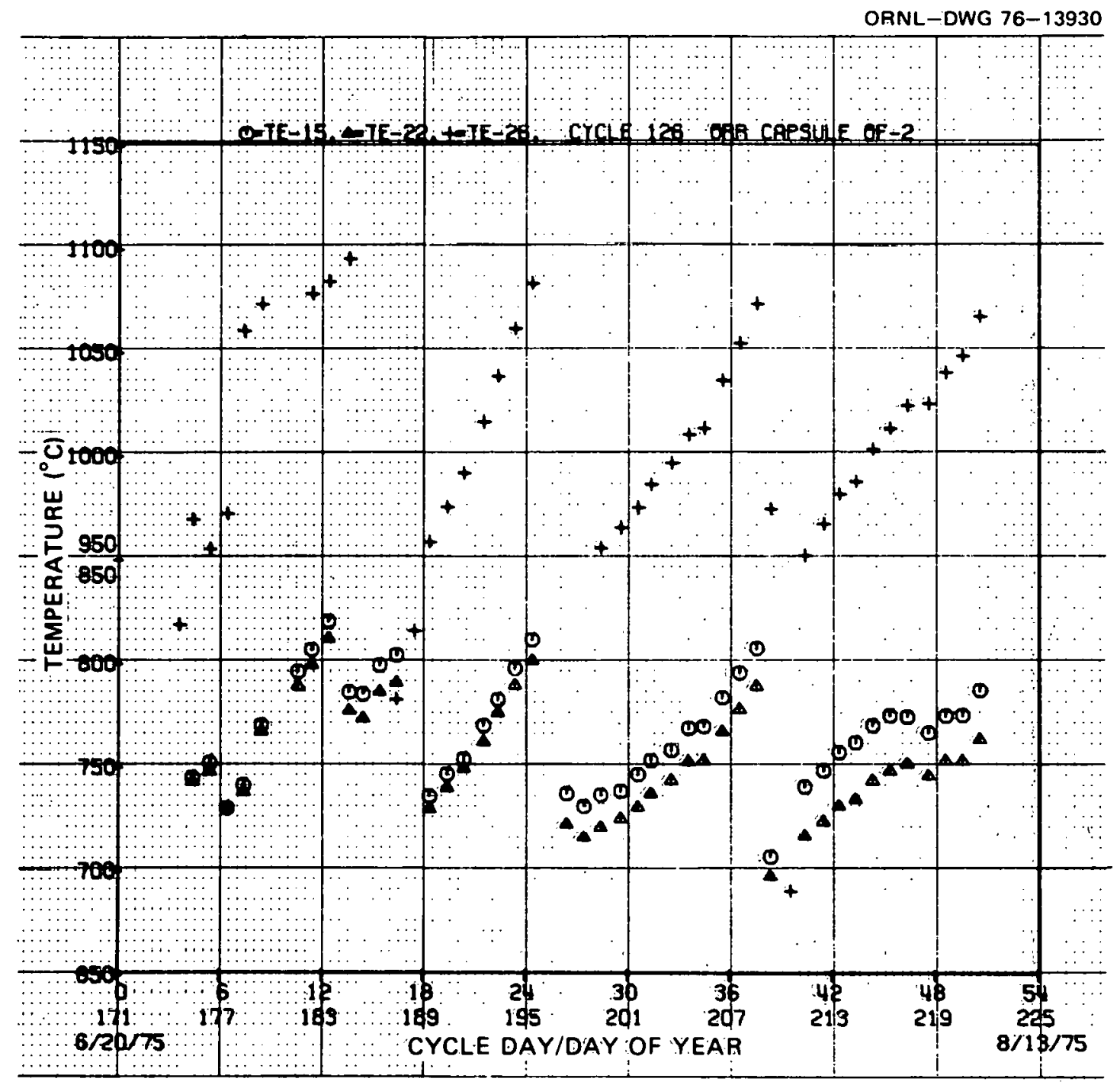




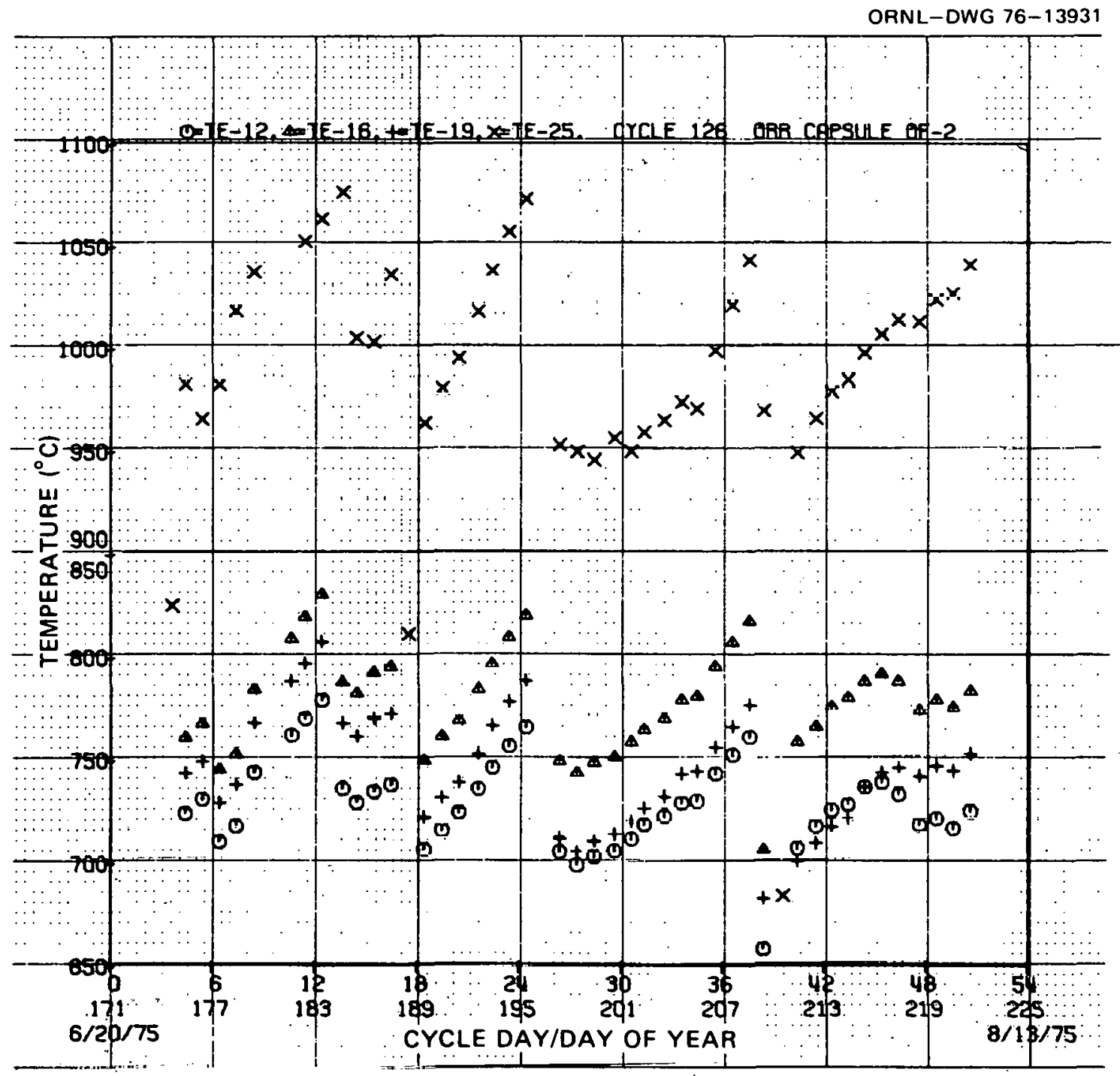




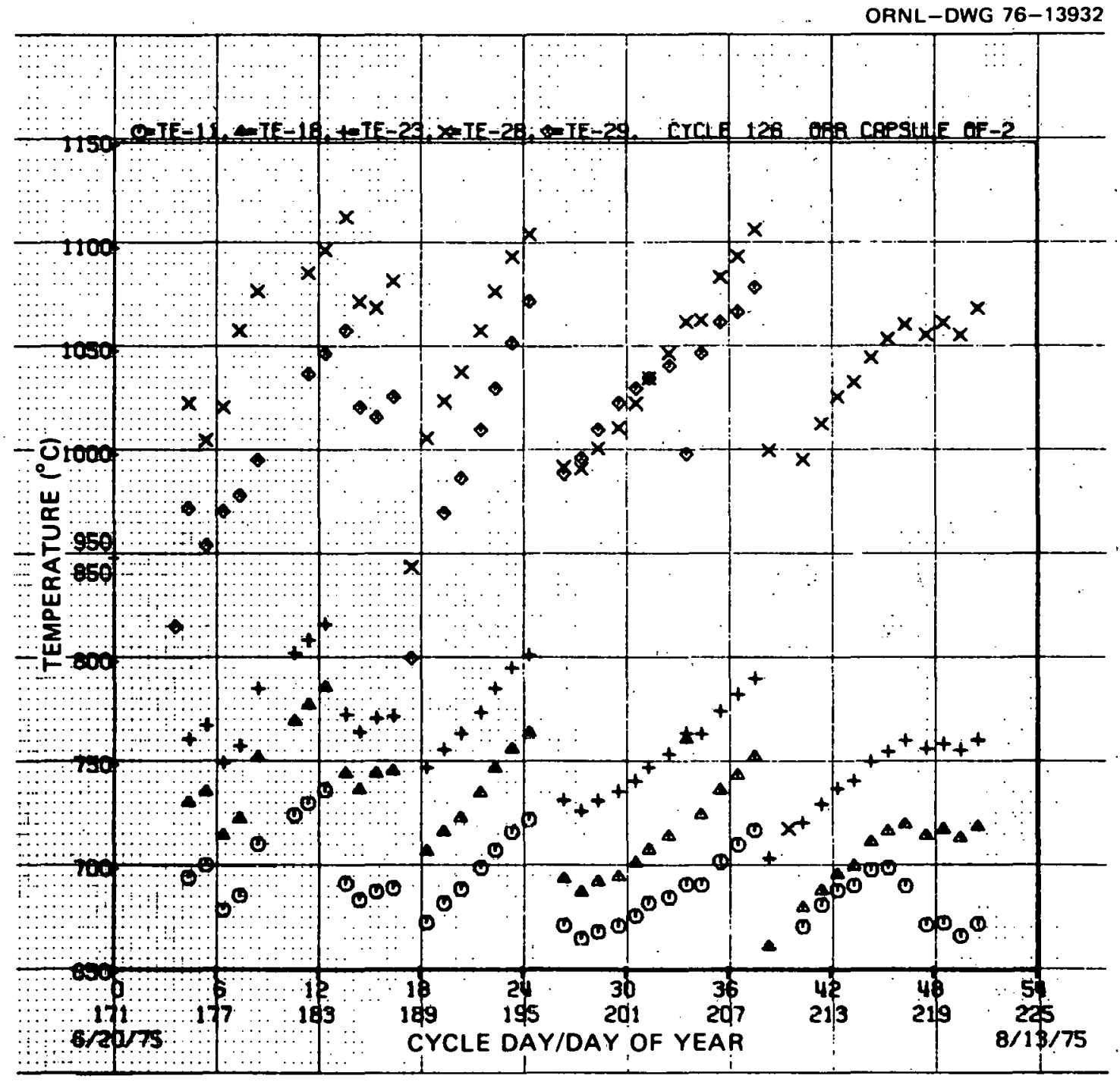




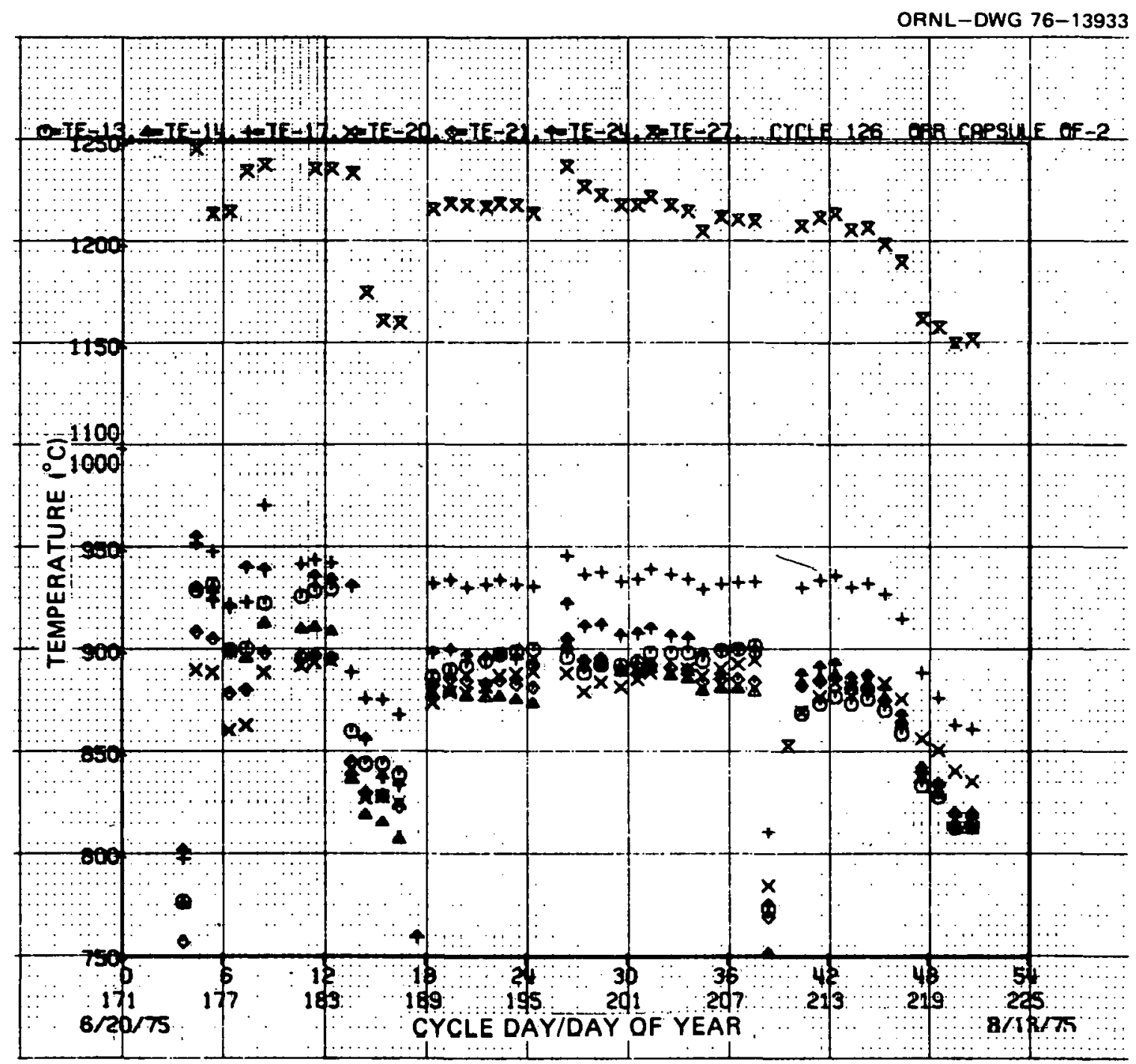




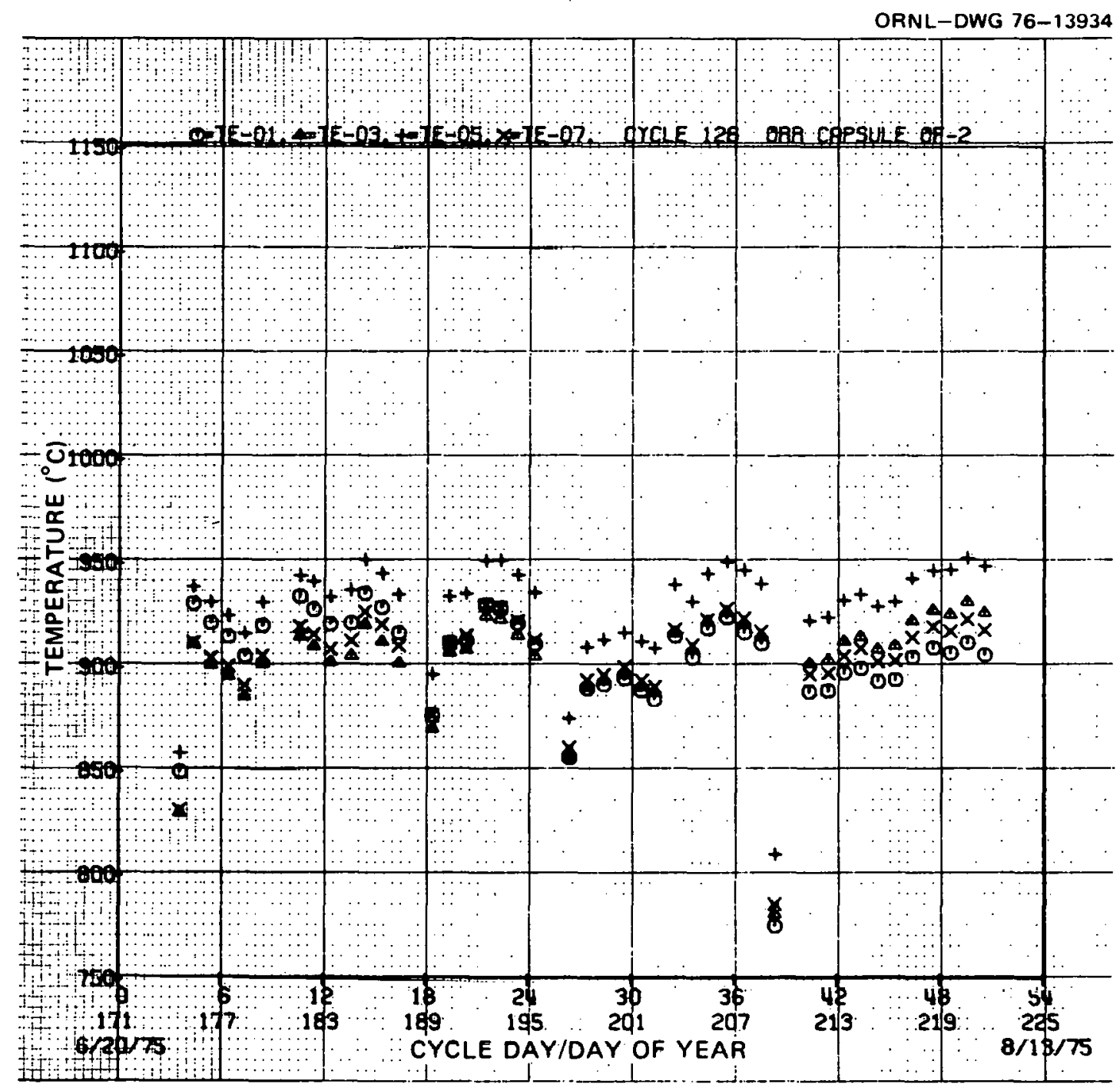


ORNL-OWG 76-13935

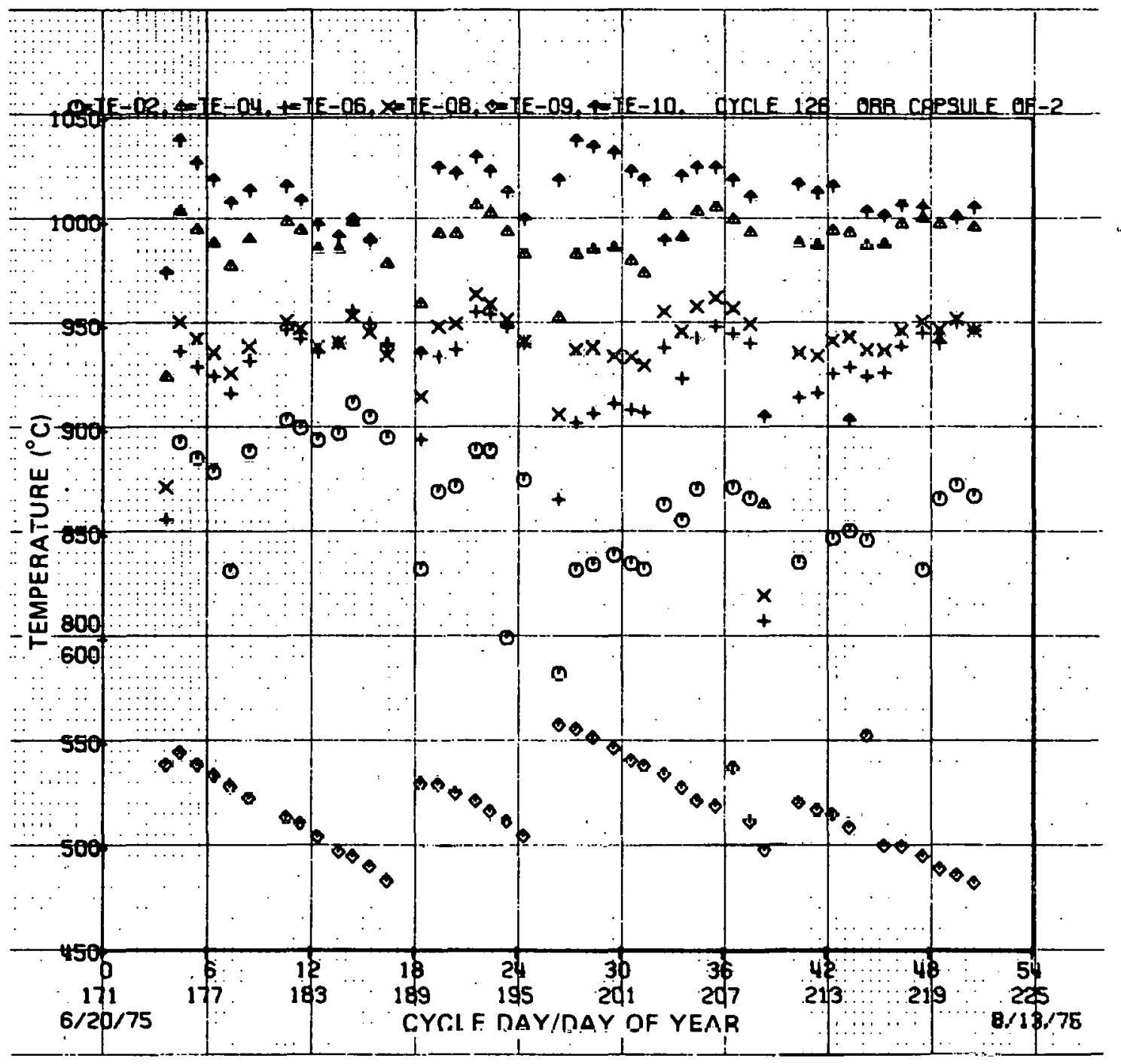


ORNL/TM-5459

Dist. Category UC-77

INTERNAL DISTRIBUTION

1. E. J. Allen

2. S. Baron

3. R. I. Beatty

4. E. S. Bomar

5. R. A. Bradley

6. C. D. Cagle

7. A. J. Caputo

8. J. A. Conlin, Jr.

9. J. H. Coobs

10. W. E. Cooper

11. D. Costanzo

12. F. L. Culler

13. W. P. Eatherly

14. J. I. Federer

15. G. G. Fee

16. M. J. Goglia

17. P. A. Haas

18. R. L. Hamner

19. J. F. Harvey

20. M. R. Hill

21. F. J. Homan

22. D. R. Johnson

23-27. M. J. Kania

28-30. P. R. Kasten

31. H. T. Kerr

32. W. J. Lackey

33. M. Levenson

34. T. B. Lindemer
35. E. L. Long, Jr.

36. A. W. Longest

37. A. L. Lotts

38. R. E. MacPherson

39. C. S. Morgan

40. R. L. Pearson

41. W. H. Pechin

42. H. Postma

43. J M Robbins

44. J. D. Sease

45. R. L. Senn

46. M. R. Sheldon

47. R. I. Shepard

48. V. J. Tennery

49. T. N. Tiegs

50-54. K. R. Thoms

55. D. B. Trauger

56. K. H. Valentine

57. P. Wagner

58. G. W. Webber

59. J. R. Weir

60. W. J. Wilcox

61. ORNL Patent office

62-63. Central Research Library

64. Document Reference Section

65-67. Laboratory Records Department

68. Laboratory Records (RC)

EXTERNAL DISTRIBUTION

69-70. Director, Division of Nuclear Research and Application, ERDA, Washington, D.C. 20545

71. Director, Reactor Division, ERDA, ORO

72. Research and Technical Support Division, ERDA, ORO

73-249. For distribution as shown in TID-4500 under catagory UC-77, GasCooled Reactor Technology 